\title{
The Safavid-Qizilbash Ecumene and the Formation of the Qizilbash-Alevi Community in the Ottoman Empire, c. 1500-c. 1700
}

\section{Rıza Yıldırım}

To cite this article: Rıza Yıldırım (2019) The Safavid-Qizilbash Ecumene and the Formation of the Qizilbash-Alevi Community in the Ottoman Empire, c. 1500-c. 1700, Iranian Studies, 52:3-4, 449-483, DOI: $10.1080 / 00210862.2019 .1646120$

To link to this article: https://doi.org/10.1080/00210862.2019.1646120

曲 Published online: 27 Sep 2019.

Submit your article to this journal

Џ Article views: 227

Q View related articles $\sqsubset$

View Crossmark data \lceil 


\section{The Safavid-Qizilbash Ecumene and the Formation of the Qizilbash-Alevi Community in the Ottoman Empire, c. 1500-c. 1700}

Alevis, the largest religious minority of Turkey, also living in Europe and the Balkans, are distinguished from both Sunnis and Shicites by their latitudinarian attitude toward Islamic Law. Conceptualizing this feature as "heterodoxy," earlier Turkish scholarship sought the roots of Alevi religiosity in Turkish traditions which traced back to Central Asia, on the one hand, and in medieval Anatolian Sufi orders such as the Yasawi, Bektashi, Qalandari, and Wafa'i, on the other. A new line of scholarship has critiqued the earlier conceptualization of Alevis as "heterodox" as well as the assumption of Central Asian connections. In the meantime, the new scholarship too has focused on medieval Anatolian Sufi orders, especially the Bektashi and Wafa ${ }^{3}$, as the fountainhead of Alevi tradition. Critically engaging with both scholarships, this paper argues that it was the Safavid-Qizilbash movement in Anatolia, Azerbaijan, and Iran rather than medieval Sufi orders, that gave birth to Alevi religiosity.

Keywords: Alevi; Qizilbash; Safavids; Bektashi; Turkoman; Ottomans; Sufi Orders

\section{Introduction}

At approximately 15 percent of the population, Alevis constitute the largest religious minority group in Turkey. Aside from the main body living within the borders of modern Turkey, there are related Alevi groups in surrounding regions once ruled by the Ottoman and the Safavid empires, as well as a substantial population among immigrant communities in Europe. Alevis have been studied by Turkish scholars since the beginning of the twentieth century. The study of the Alevi religion was established by Fuat Köprülü and developed by Irène Mélikoff and Ahmet Yaşar Ocak. They

Riza Yildirim completed his first PhD in Ottoman history at Bilkent University in 2008 and is currently writing his second doctoral dissertation in Religious Studies at Emory University. In his first dissertation and subsequent research, he studied the history of Qizilbash-Alevi and Bektashi communities in the region stretching from Iran to the Balkans. His second doctoral project focuses on sharica-inattentive Muslim pieties (so called "Ghulat") in Iran, Iraq, Syria, and Turkey. He has published five books and several research papers on the history and religion of Qizilbash-Alevis and Bektashis.

The author would like to express his gratitude to Devin J. Stewart, Fariba Zarinebaf, Amelia Gallagher, and the anonymous reviewers of Iranian Studies for their constructive and thought-provoking comments on the earlier drafts of this paper. 
defined the Alevi religion as a Turkish heterodoxy par excellence which emerged out of Turkish popular Islam and expressed resistance to cosmopolitan Sunni orthodoxy. These scholars tried to find the roots of the Alevi tradition in medieval Sufi orders such as the Yasawi, Bektashi, Qalandari, and Wafa i. ${ }^{1}$ A recent line of revisionist scholarship raised strong criticisms of Köprülü's binary conceptualization, arguing that its sweeping generalization hinders our understanding of the multifaceted religious landscape of medieval Anatolia. The idea that the Alevi religion is a heterodoxy that developed against an imagined normative Islam, i.e. Sunni orthodoxy, has been vehemently rejected by this type of revisionist scholarship. Yet, the second component of Köprülü's paradigm, that is, considering medieval Sufi orders as the fountainhead of Alevi tradition, remains central to the new scholarship. ${ }^{2}$

Both Köprülü and his critics have paid little or no attention to the Safavid-Qizilbash movement as a constitutive element of the Alevi religious system. In this article, I argue that this is a grave misrepresentation of Alevi history for several reasons. First of all, such an unbalanced emphasis on medieval Sufi orders instead of the Qizilbash movement draws an artificial line between the categories of "Alevi" and "Qizilbash," even though it acknowledges some sort of overlap. As I will discuss below, this proposition is clearly disproved by Alevi sources that have recently come to light. These sources show that the Alevis and the Qizilbash were not two different groups. Rather, the two different names referred to one and the same religious community. Indeed, the proper historical name for Alevis, as seen in earlier sources, is Qizilbash. Using the term "Alevi" to refer to the Qizilbash became widespread only in the second half of the nineteenth century, due to the conciliatory policies of Sultan Abdulhamid II (r. 1876-1909) toward the Qizilbash. ${ }^{3}$ Therefore, I prefer to use the term "QizilbahAlevis" to indicate that the Qizilbash and the Alevis are the same community of faith. This term also highlights my focus on the Qizilbash in Ottoman territories. ${ }^{4}$

A close examination of the sources demonstrates that the socioreligious makeup, rituals, and doctrines of the Qizilbash-Alevi people were institutionalized and stabilized in the course of the Safavid-Qizilbash revolution in the late fifteenth and sixteenth centuries. This claim is supported by myriad references in their religious practices and sacred narratives to this formative period. ${ }^{5}$ Therefore, I argue that the Qizilbash-Alevis were not an extension of the Bektashi tariqah or of any other Sufi

\footnotetext{
${ }^{1}$ Köprülü, Türk Edebiyatında; Köprülü, “Anadolu'da İslamiyet”; Köprülü, "Bektaşîliğin Menşe’leri”; Köprülü, Influence du chamanisme; Köprülü, "Bektaş”; Köprülü, "Ahmet Yesevi”; Mélikoff, "L'Islam hétérodoxe”; Mélikoff, Sur les traces; Mélikoff, De l'épopée; Mélikoff, Au banquet; Ocak, "Les milieux soufis”; Ocak, "Un aperçu"; Ocak, Osmanl İmparatorluğu'nda; Ocak, "The Wafă’ì tarīqa."

${ }^{2}$ DeWeese, "Foreword”; Karamustafa, "Yesevlik, Melâmetîlik, Kalenderîlik"; Karamustafa, "Kaygusuz Abdal"; Dressler, Writing Religion; Karakaya-Stump, "The Vefä'iyye"; Karakaya-Stump, "Subjects of the Sultan." For a revisionist approach, see Yildırım, "Sunni-Orthodox vs. Shi ite-Heterodox?" For a comprehensive discussion of the literature on Alevis, see Yıldırım, Geleneksel Alevilik, 39-74.

${ }^{3}$ Yıldırım, Geleneksel Alevilik, 39-45.

${ }^{4}$ In the meantime, I use the term "Qizilbash" to signify all Qizilbash people across the Ottoman and Safavid empires and the term "Alevi" to signify modern Qizilbash living in Turkey and Europe.

${ }^{5}$ For some preliminary studies on this track of scholarship, see Yildırım, "Inventing a Sufi Tradition"; Yıldırım, "In the Name of Husayn's Blood"; Yıldırım, Aleviliğin Doğuşu.
} 
orders, such as the Yasawi, Qalandari, or Wafa'i order, but adherents of the Safavid dynasty as well as disciples of the Safavid tariqah.

Not only Turkish historiography creates a misrepresentation of Qizilbash and Alevis as two different people; so too does Safavid historiography. Though acknowledging substantial Anatolian roots of the Safavid revolution, the latter has not sufficiently considered the history of the Qizilbash-Alevis who remained in Ottoman territory. 6 This is because existing scholarship has relied on sources produced by Persian bureaucrats and Arab and Persian religious scholars. These sources are silent about the Anatolian Qizilbash. More strikingly, they include almost no information about the internal organization and religious practices of the Qizilbash who constituted the military caste of the Safavid state. Meanwhile, few of the written sources, if any, that were produced by the Qizilbash aristocracy have survived to the present day. As a result, Safavid historiography provides little information about the Qizilbash, even though they were the military and political overlords of the Safavid state.

In the meantime, remnants of the Qizilbash movement in Anatolia, i.e. the Alevis, managed to preserve some documents and manuscripts that trace back to the sixteenth and seventeenth centuries. Since they are considered sacred and kept secret, most of these sources have only become known recently. One may classify these Alevi sources under three main categories: (1) religious treatises and guidebooks, (2) authorization documents such as the diploma of khilafat (shajarah) and the diploma of sayyidhood (siyādatnāmah), and (3) letters addressed to local Qizilbash-Alevi communities or individuals. ${ }^{7}$

Among the religious treatises and guidebooks, the most important and the most central for the Qizilbash-Alevi religious system is a genre of religious writing called Manäqib-e Shaykh Safì, more popularly known among contemporary Alevis as the Buyruk ("Command"). Scholars have assumed that the Buyruk genre consists exclusively of Alevi texts, whose origin goes back to the Safavid propaganda among Ottoman Qizilbash in the sixteenth century and that it has no relevance to the Qizilbash in the Safavid world. ${ }^{8}$ My own studies, based on more than fifty copies

\footnotetext{
${ }^{6}$ For the most relevant studies in this respect, see the following section in this paper. For an approach that seeks to link the Ottoman and the Safavid aspects, see Zarinebaf, "Rebels and Renegades."

${ }^{7}$ Most of the newly discovered documents that fall into the second and third categories in my classification are published in the following works: Ocak, Ortaçă̆ Anadolu'sunda; Aytaş, Belgeler Işı̆ğında; Karakaya-Stump, "Subjects of the Sultan"; Karakaya-Stump, "Documents and Buyruk Manuscripts"; Karakaya-Stump, Vefailik, Bektaşilik, Kizılbaşlık. During my own field studies in more than 600 Alevi villages in the years 2013, 2014, and 2015, I discovered some 250 manuscripts dealing with the Alevi faith and rituals. Most frequent among these manuscripts are copies of Buyruk, Fażiletnämeh (a legendary account of 'Alī Ibn Abī TTālib’s deeds written in 1519), Maqtal-e Husayn (a legendary narrative of Imam Husayn's martyrdom), and collections of Shah Ismail's poems under the penname Shah Khatāî. For my preliminary discussions of the data collected in this fieldwork, see Yildırım, Geleneksel Alevilik; see especially pp. 295-302 for a discussion of these manuscripts. For an introductory evaluation of Alevi written sources, see Yildırım, "Literary Foundations."

${ }^{8}$ For the most important studies on the Buyruk, see Otter-Beaujean, "Schriftliche Überlieferung versus mündliche Tradition"; Yaman, "Alevilerin İnanç ve İbadetlerinin Temel Kitabı"; Yaman, Buyruk; Kaplan, "Buyruklara Göre Kızılbaşlık”; Kaplan, Erkânnâme 1; Kaplan, Yazılı Kaynaklarına Göre Alevilik;
} 
that I discovered in public libraries and among the private possessions of Alevi religious leaders, have led me to conclude otherwise. I argue that the Buyruk emerged in the sixteenth century as the canonical text of the Safavid-Qizilbash Sufi order, that is, the Safavid Sufi order as it was transformed under Shaykh Junayd, Shaykh Haydar, and Shah Ismail. Hence, it addressed not only the Qizilbash followers in Ottoman territory but also the Qizilbash aristocracy within the Safavid realm.

This study suggests that these recently discovered Qizilbash-Alevi sources may significantly extend our knowledge of Qizilbash-Alevi history. They may also shed a light on the above-mentioned absent aspect of Safavid history. To this end, this study scrutinizes the internal socioreligious organization and religiosity of the Qizilbash-Alevi people mainly through these Alevi sources. Finally, it argues that the Qizilbash in the Ottoman and Safavid territories were the integral parts of the same socioreligious ecumene, that is, the Safavid-Qizilbash order. Hence, the history of the QizilbashAlevis of modern Turkey is part of the history of the Safavid-Qizilbash.

\section{Formation of the Safavid-Qizilbash Sufi Order and the Anatolian Branch of the Safavid-Qizilbash Ecumene}

Since the 1930s, scholars have noticed close ties between Anatolian Turkomans and the transmutation of the Safavid Sufi order by the mid-fifteenth century. ${ }^{10}$ Hanna Sohrweide convincingly documented the Anatolian roots of the Safavid/Qizilbash revolution. ${ }^{11}$ Concomitantly, studies by Jean Aubin, Roger M. Savory, Hans Roemer, and Michel M. Mazzaoui further expanded our understanding of the revolutionary period in the Safavid history. ${ }^{12}$ One point on which this foundational literature agrees is that the transformation of Shaykh Safî's quietist and Sunni-oriented tariqah into a Messianic revolutionary movement was, above all, due to Turkoman disciples who hailed from among tribes of Anatolia, Syria, and Azerbaijan. Under the energetic leadership of young Shaykh Junayd (1447-60), the Safavid order turned into a uniting locus for dissident Turkomans who resided in Ottoman, Aqquyunlu, Zulqadirlu, and Mamluk territories. ${ }^{13}$ The mass adherence of these

Kaplan, Şeyh Safî Buyruğu; Bisâtî, Şeyh Sâfî Buyruğu; Taşğın, "Şeyh Safi Menâkıbı ve Buyruklar"; Karakaya-Stump, "Documents and Buyruk Manuscripts"; Karakaya-Stump, "Alevi Dede Ailelerine Ait Buyruk Mecmuaları."

${ }^{9}$ For an extensive discussion of the historical, social and religious context of the Buyruk and a critical edition of the earliest Buyruk text, see Yıldırım, Menâkıb-ı Evliyâa (Buyruk).

${ }^{10}$ Hinz, Irans Aufstieg; Minorsky, "The Poetry of Shah Ismail I"; Minorsky, Tadhkirat al-Muluk.

${ }^{11}$ Sohrweide, "Der Sieg."

${ }^{12}$ Roemer, "Die Safawiden"; Roemer, "The Qizilbash Turcomans"; Nikitine, "Essai d'Analyse"; Savory, Iran under the Safavids; Savory, "Some Reflections"; Savory, "The Consolidation"; Savory, "The Office of Khalifat Al-Khulafä"; Savory, "The Principal Offices"; Aubin, "Études Safavides I"; Aubin , "L'avènement des Safavides"; Aubin , "Revolution chiite"; Mazzaoui, The Origins; Mazzaoui, "The Ghāzī Backgrounds"; Haneda, Le Châh et les Qizilbâs.

${ }^{13}$ In addition to works cited above, especially for the Turkoman political tradition in the background of the Safavid revolution, see Woods, The Aqquyunlu. 
Turkomans to the Safavid dynasty fundamentally altered the doctrine and organizational structure of the Sufi order. When Shaykh Junayd's revolution reached its climax under his grandson Ismail in 1501, both the leadership and the constituency of the Safavid order were dominated by Turkoman tribespeople.

Shah Ismail's call to rally his loyal disciples in the summer of 1500 was answered by the very same tribal people who had provided sanctuary for his grandfather half a century earlier. And it was this army of 7,000 troops that constituted the political and military nucleus of the Safavid state in 1501. Ismail's army was composed of fighters belonging to the Rumlu, Ustajlu, Tekelu, Varsak, Shamlu, Zulqadirlu, Avshar, and Karajadaghlu tribes. Among these semi-nomadic tribes, the Karajadagh Sufis and a portion of the Avshars lived in Azerbaijan, and the Shamlu had their winter quarters in Syria, with their grazing pasturelands stretching to central Anatolia (Sivas). The rest of the army came from various regions of Anatolia. Likewise, the leaders of Anatolian Turkoman tribes such as Tekelu, Ustajlu, Rumlu, and Zulqadirlu became major politico-military actors in Safavid politics during the sixteenth century. ${ }^{14}$ Furthermore, Turkoman immigration from Ottoman, Zulqadir, and Mamluk territories to Iran continued after the foundation of the state. As we learn from the eyewitness account of an anonymous Italian merchant, men were continually flocking from Anatolia to the standard of Shah Ismail during the first two decades of the sixteenth century. ${ }^{15}$

The massive Qizilbash immigration from Anatolia to Azerbaijan and Iran is attested by various Ottoman sources. For example, copies of imperial edicts issued by the Ottoman central government in June and July 1501 reveal that the Ottoman administration was well aware of the close connection between the Sufis of Ardabil residing in Ottoman lands and the emerging Safavid power in Azerbaijan. ${ }^{16}$ Seven edicts issued between mid-June and mid-July 1501 show that Bayezid II implemented severe measures to stop movement across the eastern borders of the empire. ${ }^{17}$ Apart from the archival sources, the eastward Qizilbash migration is also evinced in writings by Ottoman bureaucrats and religious scholars who served under Bayezid II (r. 1481-1512) and Selim I (r. 1512-20). For example, Āşıkpaşazāde recorded in 1502 that Shah Ismail had many disciples in Ottoman territories and that they maintained continual contact with the Dargāh of Ardabil. ${ }^{18}$ This issue comes up frequently in Selim-name literature devoted to the official histories of Sultan

\footnotetext{
${ }^{14}$ Faruk Sümer's monograph is still the most comprehensive treatment of the Anatolian roots of the Safavid military caste. See Sümer, Safevi Devletinin Kuruluşu. Also consider Yıldırım, "Turkomans," 246-302; Yildirım, "The Rise of the Safavids." A full list of the Safavid army recorded in a sixteenthcentury Ottoman source clearly shows the dominance of the Anatolian Qizilbash in its tribal composition. See Yıldırım, "Turkomans," 284-5; Yıldırım, Aleviliğin Doğuşu, 268.

${ }^{15}$ Grey, $A$ Narrative, 194.

${ }^{16}$ The entire register is published in Şahin and Emecen, Osmanlılarda Dîvân.

${ }^{17}$ Gilles Veinstein has discussed historical contents of these documents in his "Les premières mesures." For a detailed discussion of these imperial edicts in the context of the Ottoman counter-measures, see Yıldırım, "Turkomans," 324-33; Yıldırım, Aleviliğin Doğuşu, 290-9.

${ }^{18}$ Aşıkpaşazâde, Tevârih, 251.
} 
Selim I, ${ }^{19}$ as well as in books by Idris Bidlisī (d. 1520), Kemal Paşazāde (d. 1536), Celalzāde (d. 1567), and Hoca Saadeddin (d. 1599). They unanimously report that a large segment of Ottoman society became devotees of the Safavid cause. ${ }^{20}$ For example, Kemal Paşazāde wrote:

Shah Ismail the heretic was sitting in the ominous land of Gilan taking refuge in the corner of oblivion. When he came to Erzincan, taking advantage of the civil war among the Aqquyunlu princes, he dispatched envoys to khalifahs and disciples in Anatolia. The rebellious youth of the Teke Turkomans who joined his camp received privileges [from the shah]; they in turn became famous among the Qizilbash for their comradeship and chivalry. Those men of low standing who had never been appointed as fief (timār) holders and had never enjoyed respect in their own lands became commanders of troops and received high respect. Because of that they abandoned their work, deserted their homes and fields, and left their homeland [for Iran]. ${ }^{21}$

In short, both Safavid and Ottoman sources evince that during the second half of the fifteenth century, a significant portion of Turkoman tribes living in Anatolia, Syria, and Azerbaijan pledged their allegiance to the Safavid Sufi order. As I have discussed elsewhere, the rapprochement between the Turkoman masses and the Safavid Sufi order was a part of broader political and religious change taking place in the Middle East. The mid-fifteenth century marks the beginning of a sea change in political culture and religiopolitical order in Anatolia, Iran, and neighboring regions. From the mid-fifteenth century onwards, the post-Mongol religiopolitical order was gradually superseded by the neo-caliphal religiopolitical order, a development which alienated Turkoman tribes who were the military overlords of the post-Mongol order. The aligning of Turkoman tribes and the Safavid Sufi order was a response to this new political tendency, most of all in the Ottoman empire and to a lesser extent in the Aqquyunlu state. ${ }^{22}$

It was this alliance between the Turkomans and the Safavid shaykh family that transformed the Safavid tariqah and stimulated revolutionary aspirations. In terms of doctrine, ritual, and organizational structure, the revolutionary period marks a crucial transformation within the Safavid Sufi order. In the context of a millenarian political revolution, the quietist Sufi order of Shaykh Șafì al-Dìn (d. 1334) split

\footnotetext{
${ }^{19}$ For this particular historiographical sub-genre, which aimed to whitewash Selim I's unprecedented practices during the civil war, see Tekindağ, "Selim-nâmeler"; Çı̣pa, The Making, 111-31. For a critical review of Erdem Çıpa's book, see Yılmaz, "Selim'i Yazmak."

${ }^{20}$ Kemalpaşazâde, Tevârih, 1985, 43; Kemalpaşazâde, Tevârih, 1997, 233; Celâl-zâde, Selim-nâme, 208-9; Bitlisî, Selim Şah-nâme, 12; Kreutel, Haniwaldanus, 39-45; Hoca Sadettin Efendi, TacütTevarih, vol III, 345-6. For a thorough analysis of Ottoman religious discourse about Qizilbash beliefs, see Yildırım, "Turkomans," 519-64.

${ }^{21}$ Kemalpaşazâde, Tevârih, 1985, 43 [Translation from Ottoman Turkish is mine].

${ }^{22}$ Yildırım, "Turkomans," 63-244; Y1ldırım, "The Rise of the 'Religion and State' Order," Yildırım, "The Rise of the Safavids."
} 
into two branches. One maintained the traditional, Sunni-oriented, and urban-based Sufism, while the other merged with Turkoman religiosity and increasingly adopted Shicite, Messianic, and unorthodox elements from the Turkoman politicoreligious milieu. After two decades of struggle, the latter triumphed and became the mainstream of the Safavid Sufi establishment. This new form of Safavid Sufism was a synthesis of the old tradition of the Ardabil Dargāh and Turkoman religiosity. ${ }^{23}$ One may call this peculiar Sufi formation the "Second Safavid Sufi order," the "Safavid-Qizilbash Sufi order," or simply the "Qizilbash Sufism." The Safavid-Qizilbash Sufi order served as both ideological stimulus and organizational infrastructure of the Safavid revolution, which eventually begot the Safavid state.

The Safavid-Qizilbash Sufi order bound previously independent Turkoman tribes to one another in a system of religious and political affiliations. Concomitantly, these tribal people were cut off from the rest of Muslim society that did not join the Safavid cause. As a result, combining tribal constituencies (called uymaq) within a framework of Sufi loyalty and tariqah organization created a distinct socioreligious group alternately called the Safavid Sufis, the Sufis of Ardabil or the Qizilbash. When the Safavid state was founded, this group assumed the military and political/administrative posts, forming the ruling military caste of Safavid society. Although we do not know for sure, by the time of Shah Ismail the Qizilbash had probably already isolated themselves from the rest of the society on the basis of tribal lineage and tariqah affiliation. In other words, by this time, all members of the Qizilbash tribal confederation were strictly identified, and only the people of those tribes could be accepted into the Safavid-Qizilbash Sufi order.

During the sixteenth century, all Safavid military posts and the great majority of administrative posts were held by members of the Safavid-Qizilbash Sufi order. This is to say that the Second Safavid Sufi order functioned as the religion of the military caste in the Safavid empire. The line of separation between the ruling military caste and the ruled subjects was drawn not only on an ethnic basis but also by religious means. It is important to underscore that, and this has for the most part escaped the attention of modern Safavid historians, the relationships within the Qizilbash community were regulated by the rituals and principles of the Safavid-Qizilbash Sufi order and not by Twelver Shi ite law. The rules and regulations of the Safavid-Qizilbash Sufi order, referred to as "Șüfigarī" in contemporary sources, assumed the role of the qainūn (state law) in other Turkish states such as those of the Aqquyunlus, the Ottomans, and the Mamluks. ${ }^{24}$ This is to say, ever since the inception of Twelver

\footnotetext{
${ }^{23}$ For a detailed discussion of this process, see Yıldırım, "Turkomans," 168-244; Yıldırım, "In the Name of'; Yıldırım, Aleviliğin Doğuşu, 157-222.

${ }^{24}$ This aspect of the Safavid-Qizilbash Sufi order has received little attention in scholarship. This is chiefly because Safavid historians mention Qizilbash rituals only sporadically; and these sporadic short accounts have for the most part escaped the notice of modern scholars. As a result, we know little about Qizilbash rituals and how they functioned as primary means of organization among the Safavid military elite. Further studies on the above-mentioned Qizilbash-Alevi sources may potentially help us to learn more about specific Qizilbash rituals and practices. For a study of the Qizilbash "beating ritual" based primarily on Michel Membrés travelogue and Safavid sources, see Morton, "The Chüb-i
} 
Shi ism as the official religion in Safavid Iran, we see two separate religious systems operating simultaneously: (1) Qizilbash Sufism as the religion and organizational basis (quasi-law) of the ruling military caste, and (2) Twelver Shicism, which had long before developed into the form of madhhab, that is, a law-based Islamic religion. I term the former religious system, together with the social order that merged with it, the "Safavid-Qizilbash ecumene."

The members of the Safavid-Qizilbash ecumene were not limited to the military caste in the Safavid realm, but also included their brothers and sisters in Ottoman Anatolia, who were mostly their relatives who had remained in Anatolia during the revolutionary period. The Ottoman sources mentioned above attest that not all of the Qizilbash communities in Anatolia immigrated to the Safavid empire. Many relatives of those tribesmen who joined the Safavid ruling cadres were left behind in various regions of Anatolia, then ruled by the Ottomans, the Zulqadir Principality, and the Mamluks. By the end of Selim I's reign in 1520, all of these Qizilbash-inhabited zones had been annexed to Ottoman territory. Although the connection between the Safavid center and the Anatolian followers was weakened by the preventive measures of the Ottoman administration, it was never severed up until the collapse of the Safavid dynasty in the second quarter of the eighteenth century.

Both Ottoman and Alevi sources leave no doubt that the Qizilbash in the Ottoman realm were considered as members of the Safavid-Qizilbash Sufi order, just as the Qizilbash in the Safavid Empire were. They were organized and religiously administered by khalifahs appointed by the khalifat al-khulafā (the alter ego of the shah in the order), they collected and sent money to the shah as a part of their religious duties and, above all, they believed in the living Safavid shah as the highest religious authority, their perfect spiritual director (murshid-e kamil). The Qizilbash of Anatolia remained as members of the Safavid-Qizilbash ecumene until the collapse of the Safavid dynasty. Hence, as opposed to the common wisdom, my studies suggest that during the sixteenth century Qizilbash-Alevi communities did not have any affiliation to the Bektashi Sufi order whatsoever. Likewise, they maintained their adherence to the Safavid-Qizilbash Sufi order until the end of the seventeenth century, albeit with less enthusiasm. Thenceforth, some Qizilbash groups in Western Anatolia converged with the Bektashi Sufi order, which was granted legal status under Ottoman rule, while others developed other strategies to survive as isolated compact communities. ${ }^{25}$ Those whom we call "Alevis" today are the descendants of those Qizilbash communities in Anatolia.

\footnotetext{
TTariq." For an introductory analysis of Süfigari as a "law of the state," see Yıldırım, "The Rise of the Safavids."

${ }^{25}$ For an evaluation of the relations between the Qizilbash-Alevis and the Bektaşi Sufi order during the post-Safavid era, see Yıldırım, Bektaşiliğin Doğuşu, 313-36.
} 


\section{Triumph of Chiliastic Aspirations}

The post-revolutionary history of the Anatolian Qizilbash has two main phases: (1) from the foundation of the Safavid State until Shah Ismail's first and decisive defeat in Chaldiran in 1514, and (2) from Chaldiran to the decline of the Safavid dynasty in the first half of the eighteenth century. Shah Ismail's departure from Lahijan in 1499 and his subsequent overthrow of the Aqquyunlu dynasty in 1501 created a wave of millennial excitement among the Sufis of Ardabil from Iran to the Balkans. Many Qizilbash tribesmen under Ottoman rule rushed to join the shah's revolution (khurüj). They joined the shah's army in 1500 in Erzincan, leaving their elders, women, children, and livestock behind in their summer pastures. ${ }^{26}$ It is amply clear from contemporary sources that those Qizilbash who remained in the Ottoman territories believed in the utopian prediction that Shah Ismail would march into Anatolia and terminate Ottoman rule. ${ }^{27}$

Following these developments closely and with alarm, the Ottoman administration took immediate measures on the borders and in the provinces that housed a large number of Safavid adherents. Out of fear of looming chaos in Anatolia, Ottoman officials deported many Qizilbash from the province of Teke in southwestern Anatolia to the newly conquered Peloponnese. ${ }^{28}$ The excitement among the Qizilbash in Anatolia and the Ottoman response reveal that expectation of the shah's march on Anatolia was in the air. However, this hope was never fulfilled, since Shah Ismail was too occupied with conquering Persian Iraq, Iran, and Khurasan. Most of all, another rising power to the east in Central Asia, namely the Uzbek Khanate, proved to be a formidable enemy the shah was forced to deal with. While the Ottoman state was involved in a civil war between 1510 and 1512, which would be an opportune time for a Qizilbash advancement in Anatolia, the Uzbeks took Shah Ismail's full attention in the east; hence, he could not launch an organized campaign on Ottoman territory.

Yet the Qizilbash in Anatolia initiated large-scale armed insurgencies across the peninsula that shook Ottoman rule to the core. The largest and the most successful revolt among them was the Shah Qulu rebellion that began in Teke and spread to western Anatolia. The leader of this rebellion, Shah Qulu, was the khalifah of the Qizilbash in Teke region. He inherited this post from his father Hasan Khalifah, who had been trained in Ardabil under Shaykh Haydar (d. 1488) and was appointed as the khalifah of the Teke province. Shah Qulu's uprising was suppressed in the summer of $1511 .{ }^{29}$ This was followed by many small-scale insurrections in central Anatolia. The uprising led by Nūr 'Alī Khalifah, who was commissioned by Shah

\footnotetext{
${ }^{26}$ For a detailed discussion of Shah Ismail's advent (khurūj), see Yıldırım, Aleviliğin Doğuşu, 223-86; Yıldırım, "The Rise of the Safavids."

${ }^{27}$ For a discussion of the Qizilbash beliefs in the revolutionary era, see Yildırım, "In the Name of."

${ }^{28}$ For a broader treatment, see Yildırım, "Turkomans," 287-304.

${ }^{29}$ Uluçay "Yavuz Sultan"; Tekindağ, "Şah Kulu"; Tekindağ, "Yeni Kaynak." For a thorough investigation of Shah Qulu's rebellion and its socioreligious context, see Yıldırım, "Turkomans," $345-415$.
} 
Ismail to organize the Sufis in the Province of Rum (i.e., the region of Tokat, Amasya, Sivas, Çorum), developed into another large-scale rebellion. Even Ottoman princes were allured by Ismail's messianic charisma and cooperated with the Qizilbash khalifahs. ${ }^{30}$ With confidence in the imminent arrival of the shah, Nūr 'Ali Khalifah managed to capture Tokat, where he read the Friday sermon in the name of Shah Ismail and held the control of the city for some forty days. ${ }^{31}$

However, Selim I's ascent to the Ottoman throne on 24 April 1512 turned the tide. After executing all the male members of the dynasty except for his son Suleyman, he mobilized the Ottoman state against the Qizilbash menace. Before the Chaldiran campaign, he blacklisted all Qizilbash-related subjects and executed "tens of thousands" of them. ${ }^{32}$ The shah's ultimate defeat in 1514 dealt a heavy blow to the messianic expectations of his ardent adherents, who believed that he was invincible. Its effect on the Anatolian Qizilbash was much more transformative. As millennial aspirations receded, the militant character of the Qizilbash identity in Anatolia weakened, while its religious and social aspects were even more reinforced. In the course of the subsequent two centuries, most of the Qizilbash on the Ottoman side of the border were transformed into isolated village communities within the Ottoman Sunni environment. In this way, Qizilbash identity metamorphosed into a socioreligious system that invested the community with the capacity to survive and sustain a self-sufficient rural life under Ottoman rule.

\section{Survival Strategies under Persecution}

This second phase of Qizilbash history is best documented in copies of decisions that were made in the Ottoman Imperial Council (Divañ-e Humāyün). These imperial orders are collected in a series of registers called Mühimme Defterleri or the Registers of Important Affairs, which cover the period after the mid-sixteenth century. Although these reports were written from an Ottoman point of view and were vehemently antagonistic toward the Qizilbash, a careful reading of them reveals considerable information about the social organization and religious praxis of Qizilbash communities. ${ }^{33}$

\footnotetext{
${ }^{30}$ Yildirım, "An Ottoman Prince."

${ }^{31}$ For an extensive discussion of Qizilbash uprisings during the Ottoman civil war, see Yıldırım, “Turkomans," 345-415, 449-99.

${ }^{32}$ Ottoman historians boast that Selim I had killed 40,000 Qizilbash before launching the Chaldiran campaign. Immediately after capturing the throne, he dispatched decrees to local governors ordering them to register the names of all disciples and sympathizers of Shah Ismail, be they young or old, and he had them slaughtered on the eve of his march on the shah. See İdrîs Bitlisî, Selim Şah-nâme, 130; Hoca Sadettin, Tacü't-Tevarih, vol IV, 176; Gelibolulu Mustafa 'Âli, Kitabu't-Tarih, 1076-7; Müneccimbaşı, Sahaif-ül-Abbar, 457; Solakzâde, Solakzâde Taribi, 16; Hammer, Büyük Osmanlı Tarihi, vol. 2, 583. Some historians rightfully suggest that we should take this statement as a conventional figure indicating large numbers rather than an accurate statistic. Bacqué-Grammont, Les ottomans, 40.

${ }^{33}$ Reports regarding the Qizilbash in these registers have been extensively studied. For major works, see Refik, On Altıncı Asırda Rafizilik; Imber, “The Persecution”; Zarinebaf-Shahr, "Qizilbash”; Savaş, XVI: Astrda. For a fresh look at such documents, see Baltacıoglu-Brammer, "The Formation."
} 
General accusations attributed to the Qizilbash in these reports are as follows: (1) maintaining contact with Iran (which includes going back and forth, collecting offerings and taking them to the shah, and bringing books and blessed objects such as kaftans $^{34}$ and swords from Iran); (2) cursing or reviling the first three of the Four Rightly Guided Caliphs, and never bestowing their names on their children; (3) addressing Sunni Muslims as "Yazīd"; (4) assembling mixed ritual gatherings at night during which they play musical instruments and engage in sexual promiscuity; and (5) not observing the ritual prescriptions of the Sunni madhbab. ${ }^{35}$

For example, according to a report published by Zarinebaf-Shahr dating from 1574, a certain Şahverdi son of Baba Hoş and his son Hoş collected offerings (nadhr) and sacrifices (qurbān) from the villages of Ruha and Siverek and took them to Iran. It is also recorded that Baba Hoş, the father of Şahverdi, was a khaliffah of Shah Ismail; he was later executed. Şahverdi and his son were exiled to Cyprus. ${ }^{36}$ Another report from 1577 refers to a group of Qizilbash in the town $(k a z \bar{a})$ of Kusun near Tarsus. A man named Kör Tatar was apparently the khalifah of the Tokuz tribe (jamácab) with a thousand followers. He was accused of having contact with Iran and of organizing secret gatherings for their "false rites," in which women took part. ${ }^{37}$ According to a report of the governor of Kangırı (Çankırı) dated 1565, a certain Küçük 'Alī traveled back and forth to Iran, led many astray, and organized mixed gatherings of men and women; ${ }^{38}$ he was executed on the charge of Qizilbash heresy. ${ }^{39}$ One of the most interesting registers regards the Qizilbash in the province of Çorum. We learn from two decrees from 1576, one addressed to the governor (beylerbeyi) of the province of Rum and the other to the governor (bey) of Çorum and the qadi of Ortapare, that a certain Veli Faqih, who was a member of the Haman tribe ( $t \vec{a}$ if $e$ ), brought forty volumes of heretical books from Iran. When Veli died, these books remained in the trust of Nesim Faqih of the same tribe. They were accused of undermining [Sunni] Islam through disseminating the information written in these books. ${ }^{40}$

Another illuminating report concerns the Qizilbash in the Tokat and Bozok provinces. In 1579, the qadi of Artıkabad in the Province of Rum arrested a Qizilbash khalifah named Mansur son of Emir 'Alī, and forced him to testify in court. Mansur admitted in his testimony that four men named Maksud, Ismail, Hasan, and Hasan Khalifah had gathered in his house and delivered 1,500 filori to a certain Şah Bende, the agent of Emir 'Alī Khalifah who was then in Iran. They had

\footnotetext{
${ }^{34} \mathrm{~A}$ special robe designated for the khalifahs.

${ }^{35}$ Savaş, XVI: Astrda, 48-67.

${ }^{36} \mathrm{MD}$ 26.175.474. Zarinebaf-Shahr provides an English translation in Zarinebaf-Shahr, "Qizilbash," 10.

${ }^{37}$ MD 30.306.707; MD 33.221.452. Cited in Imber, "The Persecution," 250-1.

${ }^{38}$ According to the Qizilbash-Alevi faith, men and women attended religious gatherings and rituals together. Since this was so unusual among Sunni Muslims and forbidden by the religious scholars, this aspect of Qizilbash-Alevi religiosity attracted the wrath of Ottoman authorities, who interpreted it a sign of idolatry.

${ }^{39}$ MD 7.896.2454. Cited in Imber, "The Persecution," 255.

${ }^{40} \mathrm{MD}$ 27.399.958; MD 28.349.883. The transcribed text of the decree is published in Savaş, XVI: Asirda, 204-5.
} 
also given him a list of the names of 3,000 Qizilbash in the Bozok, Tokat, and Artıkabad regions. Dressed in disguise, Şah Bende would bring swords and kaftans from Iran to all khalifabs, who were to gather at Akdağ. ${ }^{41}$

These registers clearly show that, despite all kinds of perils, the Anatolian Qizilbash upheld their unwavering adherence to the Safavid-Qizilbash tariqah throughout the sixteenth century. High-level khalifahs and special heralds went back and forth, votive offerings were gathered and delivered to the Sublime Lodge, objects of investiture were brought back to Anatolia, and rituals of the tariqah were performed. This was despite the fact that the Ottoman regime inflicted heavy persecution, immediately executing or exiling even those suspected of affiliation with the Safavid-Qizilbash tariqah. ${ }^{4}$

As we learn from an Ottoman official report dated 1619 CE, there was a Qizilbash group living even in a suburb of Istanbul. ${ }^{43}$ The document includes testimony of some Qizilbash in the court of Çeşmi Efendi, the qadi of Istanbul. It is understood from this document that an investigation had been initiated by a previous imperial edict ordering the "faction of idolaters" ( $t \vec{a}$ iffeh-ye malähideb) in Istanbul to be found out and punished. The description of the Qizilbash in this document is parallel to those of the aforementioned registers. They are described as people who accepted Shah 'Abbas (r. 1587-1629) as their spiritual guide (murshid) and called his deputies khalifah. Their local spiritual guides were called rehber ("guide") and ordinary members of this religious community were called tălib ("disciple, follower"). They congregated every Thursday night in mixed rituals during which they read Shah Khațāì’s poems and prayed for Shah 'Abbas. They collected penitential fines and votive offerings, sending one-third of it to the shah as nadbr. ${ }^{44}$

Unfortunately, Safavid sources are silent about the Anatolian disciples of the Safavid shahs during the post-revolutionary period, especially after 1514. Thanks to the Venetian traveler and messenger of the doge Michel Membré, we know of at least two occasions showing the connection between Anatolian Qizilbash and Shah Tahmasb. Membré's eyewitness account not only confirms that the unwavering religious adherence of the Anatolian Qizilbash to the shah was maintained during the mid-sixteenth century but also demonstrates that the Qizilbash immigration to Iran from Ottoman territories continued throughout the century. Membré arrived at Shah Tahmasp's camp near Marand in August 1539. The next day after his arrival a Turkoman tribe of 800 household arrived at the camp seeking asylum in the shah's domain. He reports that this tribe, called the Turkomans of 'Alī, which included 600 fully armed horsemen, migrated from the Ottoman province of Arzincan with their families and animals. The shah ordered them to be divided into three

\footnotetext{
${ }^{41}$ MD 40.212.479. Cited in Imber, “The Persecution,” 260-1.

${ }^{42}$ Savaş, XVI: Asırda, 97-102.

${ }^{43}$ The extant copy of this document is recorded in a manuscript preserved in the library of the École des langues orientales vivantes, Paris (no. 103) and published with a French translation by M. A. Danon in his "Un interrogatoire." Danon's identification of this community as Bektaşi-Hurufi appears to be incorrect.

${ }^{44}$ Danon, "Un interrogatoire," 293.
} 
groups to be sent to the provinces of Khorasan, Shirvan, and Iraq. ${ }^{45}$ It seems that the immigration of Qizilbash tribes from Anatolia to Iran continued well after the sixteenth century. In 1602-4, when Shah 'Abbas was in Erivan, a tribe of 2,000 families coming from the Ottoman Anatolia displayed their loyalty, demonstrated their "love for the shah," and pledged their allegiance to him. Shah "Abbas allotted them summer and winter quarters in the provinces of Rayy, Sava, Khar, Firuzkuh, and Iraq. ${ }^{46}$

Another account that Membré records as an eyewitness demonstrates the extent of the Anatolian Qizilbash's faith in Shah Tahmasp.

At that time [1540] I saw a Turk of Anatolia come to the Shah's court asking for one of the Shah's turban-cloths, which he is accustomed to give for a high price; and for that cloth they give him a horse as a gift. And this happens secretly. I know it because there came one from Anatolia, that is from Adana, and he came to the Lord in whose house I was staying, that is Shāh qulī Khalīfa, ${ }^{47}$ and brought a bag of fine dried figs as a present for him, and begged him to speak to the Shah, so that he should give one of his kerchiefs. And he had, to give as a present to the said Shah, a horse. So the said Shāh qulī Khalīfa, with great difficulty, was able to get the said cloth; he it was who presented the horse. And when the said Turk saw the cloth, he raised his hands to heaven and praised God, and bowed his head to the ground and said "Shāh, Shäh," and was overjoyed. So he took the said cloth and went his way. I asked him what the cloth was good for, and he told me that it was a tabarruk, that is, an object of beneficial effect; and, having a sick father at home, he had seen the said Shah in a dream; and for that reason he wished for the cloth, for his father's contentment, for he would be well. Every year many such people come, but they go in secret, so none can know, except he be a man of that court. ${ }^{48}$

One can notice that Membrés report conforms with the above-discussed Mübimme accounts in that they both stress the spiritual and organizational connections between the Anatolian Qizilbash and the shah. Just like the Anatolian khalifahs and couriers whom the Ottoman authorities pursued, this Qizilbash individual paid a personal visit to the shah's court with religious motives. Likewise, he presented votive offerings and received blessed objects in return.

\footnotetext{
${ }^{45}$ Membré, Mission, 18.

${ }^{46}$ Monshi, History, vol. 2, 839.

${ }^{47}$ This man was the khaliffat al-khulafā at the time. Therefore, it was quite normal that the Sufis coming from Anatolia first paid a visit to him. For us it is fortunate that Membré stayed in his house. His fluency in Turkish enabled him grasp details with considerable accuracy. See, Morton, "The Chüb-i Tariqq," 227-8.

${ }^{48}$ Membré, Mission, 41.
} 


\section{Formation of Isolated Confessional Communities}

The above-mentioned sources document the extent to which the Safavid shahs maintained their spiritual authority and religious control over the disciples in Ottoman territory. Primary means of exercising religious and juridical authority were accepting votive offerings, bestowing tools of investiture and consecrated objects, and, most importantly, appointing khalifahs to handle religious and juridical matters in their predetermined districts or tribal units. In time, this khalifah-disciple relationship seems to have stabilized on hereditary bases. The evidence indicates that appointing a deceased khalifah's son as the khalifah over the same Qizilbash disciple group (tâlib) had been already established as usual practice in the mid-sixteenth century.

One would presume, then, that the $o c a k^{49}$ families that became the skeleton of the entire Qizilbash-Alevi system in later centuries were born out of these khalifah families. No doubt, records of these khalifahs and their assigned tälib groups were kept in the office of the khalifat al-khulafä, as one of the Mühimme reports and the Alevi sources referred to below attest. ${ }^{50}$ It is also clear from the shajarahs that the shah always kept his de jure privilege of deposing khalifahs or reappointing them to other groups of tälibs. Given the precarious circumstances, however, this practice must have been difficult and rare among the Anatolian Qizilbash. After the demise of the Safavid dynasty in the mid-eighteenth century, the Qizilbash communities under Ottoman rule were completely disconnected with Iran and developed new survival strategies. One of those strategies, perhaps the most consequential one, was the development of the ocak-talib system into its permanent form. In the absence of the Safavid authority, the pyramidal structure of the socioreligious organization transformed itself into somewhat of a feudal system of hierarchy. The established de facto hereditary bonds between ocak or dede families and their tälib groups were now sanctioned as an article of the faith. Therefore, each ocak with its tálib community turned into an autonomous socioreligious entity. The relationships between ocak constellations were also regulated in an egalitarian spirit. ${ }^{51}$

During the Safavid period, the appointment of a khalifah was certified through a special document called shajarah, which was issued from the office of the khalifat al-khulafa $\bar{a}^{52}$ A report of Mirza 'Ali Naqi Nasiri, who acted as majles-nevis in the Safavid court from 1729 to 1732, states that Sufis who had the aptitude for the office of khalifah to provide guidance (ershäd) came to the shah from various parts of the kingdom to be appointed as khalifah. In order to validate their appointment, a special document called shajarah was issued by the office of the khalifat

\footnotetext{
49 "Ocak" is the generic name for the well-known extended families that produce spiritual leaders of the Alevi community.

${ }^{50} \mathrm{MD}$ 40.212.479. Cited in Imber, "The Persecution," 260-1.

${ }^{51}$ The question of the formation of ocaks has not been adequately addressed in scholarship. These are my preliminary observations derived from Ottoman, Safavid, and Alevi sources.

${ }^{52}$ For the khalifat al-khulafä, see Savory, "The Office of Khalifat al-Khulafä"; Floor, "The Khalifeh alkholafa." Floor's study is by far the most extensive survey of sources about the office.
} 
al-khulafā. "This [shajarah] contains several conditions, indicating how to provide guidance to the people and to enjoin the good and ban the evil." 33 Unfortunately, only a few of those shajarahs have survived to the present day. ${ }^{54}$

As far as the Anatolian Qizilbash are concerned, one shajarab and one letter of investiture have been discovered among the Alevi ocak families. The shajarah has been held in the private possession of the Zeynel Abidin Ocak in Malatya. It was issued by the office of the khalifat al-khulafä in 1678 on behalf of Shah Sulayman, also known as Shah Safi II (1666-94). ${ }^{55}$ After a short invocation of God, Muhammad, 'Alī Ibn Abì Tâlib, and the Imams in Arabic, the Turkish main body of the document starts with an explanation that the Safavid order was the best among the religious paths that led people to salvation. It also states that the Safavid shaykhs were accustomed to appointing khalifahs all around the world to help those people who had fallen into ignorance and had gone astray. Accordingly, it certifies the appointment of a certain Sayyid Muhammad Țāhir as the khalifah of the Kavi community in Malatya province, then in the Ottoman territories. It also states that Muhammad Tāhir, who is referred to as "one of our disciples (tălib) in Asia Minor," had assumed the post as the successor of his father Mahmūd Khalifah. After the death of his father, Muhammad Tăhir visited the shah's court and received the shajarah there. The document states from the mouth of Shah Suleyman:

Sayyid Muhammad Ṭāhir Khalifah, the harbor of sayyidhood, came to my court that protects the people from all around the world (dargāb-e jahān-panāh), and bowed down and kissed [the threshold of] my world-embracing court in faith and sincerity, and asked for the appointment for the khilafat of the Kavi community (jamáa $a b)$, which inhabits the town of Akçadağ in Malatya province. Upon his request, the above-mentioned office of the khiläfat, which had been formerly held by his now deceased father, is bestowed by our sublime threshold upon the aforesaid person. ${ }^{56}$

Following the standard style of the shajarahs, the document urges Muhammad Țāhir's tălibs to recognize him as the deputy of the murshid-e kämil (perfect guide) in the region. It also lists Muhammad Țāhir's responsibilities as the khalifah of the aforesaid community. When comparing this shajarah with the other known Safavid shajarabs given to the khalifahs in the Safavid realm, one realizes that they are identical in terms of style and formal language. This document, alongside others that I discussed earlier, corroborates the argument that the Qizilbash in the Ottoman political

\footnotetext{
${ }^{53}$ Rahìmlū, Alqāb, 35-6.

${ }^{54}$ These khaliffah shajarahs are all issued for khalïfahs in Safavid domains. See Ardakānī and MīrJa farī, "Farmān-e Shāh Ṭahmāsb-e Șafawī”; Qā’immaqāmī, Muqaddima, 93-5; Musavi, Orta asr Azarbaijan, 174-85; Dihgan, "Farmān-e Khalīfat al-Khulafā"; Tabrizi, "Shajarah-ye Khāndān-e Șafawī."

${ }^{55} \mathrm{~A}$ facsimile copy of the document, along with its transliteration, is published in Karakaya-Stump, Vefailik, Bektaşilik, Kızılbaşlık, 79-112.

${ }^{56}$ Ibid., 95 . All translations of Alevi documents from Turkish are mine.
} 
zone were regarded as an integral part of the Qizilbash socioreligious order, or the Safavid-Qizilbash ecumene.

Two letters that were issued by the office of the khalifat al-khulafā on the authority of the Safavid shahs and sent to Anatolia in the sixteenth and the early seventeenth centuries shed further light on the internal structure of the Anatolian Qizilbash and their connection with the shah. The first letter I will examine was written in Turkish and addressed to an anonymous Qizilbash group. The original document is not known to us, but a copy of the letter was incorporated into the Buyruk compilation from the sixteenth century, of which at least six manuscript copies are extant. ${ }^{57}$ Its title reads, "This is the letter of Sayyid 'Abd al-Bāqī Efendi, who resides in the Sublime Lodge (Dargāh-e ' $\bar{A} l \bar{l}$ ); and it is addressed to the faithful of pure trust who love and adhere to the Saints (Evliyā, Arabic Awliyā)." 'Abd al-Bāqī explains the reason of writing this letter as follows:

The reason for writing this letter is to let these good tidings be known to the faithful of pure trust who have pledged allegiance to the Ocak of Shaykh Sayyid Șafi alDīn Ishāq Walī in accordance with the holy principle that "they pledged allegiance to God and his Apostle" ${ }^{58}$... [that] The commander of the field of eloquence and the gem of the alchemy of rhetoric, for whom they have been waiting for so long in patience, has drawn the sword of Dhu al-fiqār of courage and is marching out to serve the House of the Prophet and to swing his intimidating victorious sword over the [heads of] the enemies of the offspring of Muhammad ' $\mathrm{Ali}^{5}$.

As is clear from this passage, the letter was sent from the Safavid center to a group of Qizilbash, most probably in Anatolia, to let them know that the Shah was about to march on the enemy, most probably the Ottomans. We know that the Safavids pursued offensive policy against the Ottomans during the reigns of Shah Ismail (r. 1501-24) and Shah 'Abbas I (r. 1588-1629. A closer reading within the context

\footnotetext{
${ }^{57}$ All of them bear the title Manäqib-e Shaykh Safí with some extra embellishing phrases differing slightly from one copy to other. According to Abdülbaki Gölpınarll, the oldest known Buyruk manuscript was copied in 1017/1608-9. However, this manuscript is no longer available to us. It was seen by Gölpınarlı in the private library of Seyyit Muhtar in Istanbul. (Gölpınarlı, "İslâm ve Türk İllerinde," 68.) Fortunately, Gölpınarlı made a copy of this manuscript for himself. Although he does not state this explicitly, this copy is probably Mss. 181 of Konya Mevlana Müzesi Abdülbâki Gölpınarlı Kütüphanesi. A systematic content analysis of the extant Buyruk manuscripts leaves no doubt that all of these copies descend from a mother copy from the sixteenth century. For this study, I have used the manuscript preserved in Istanbul Belediyesi Ataturk Kitaplığ (Yz. 27). For a facsimile copy of the pages of this manuscript that include the above-mentioned letter, see Appendix 1. For a through discussion of the available Buyruk copies see Y1dırım, Menâkıb-ı Evliyâ (Buyruk).

${ }^{58}$ The Qur'an, 48:10.

59 "Muhammad 'Alī" is a common expression in the Qizilbash-Alevi parlance. It obviously refers to the ontological proximity of Muhammad the Prophet and 'Ali the Saint whose primordial essence are the Light of Prophethood and the Light of Sainthood. In the Qizilbash-Alevi context, it is usually ambiguous whether this expression signifies one entity as "Muhammad-Alī" or two separate personae as "Muhammad and 'Alī."
} 
of the Buyruk suggests that this letter must have been written in the sixteenth century. My studies of the Buyruk genre conclude that the earliest canonized Buyruk text was compiled during the reign of Shah Tahmasb (r. 1524-76). This book, which I call the "Shah Tahmasb Vulgate," served as the foundational text for the later religious writings of the Qizilbash and even for the Bektashis to a certain extent. ${ }^{60}$ The fact that 'Abd al-Bāqī Efendi's letter is included in the Shah Tahmasb Vulgate shows that it must be dated before the compilation of the Buyruk during the mid-sixteenth century.

No doubt 'Abd al-Bāqī Efendi must have held a high-ranking position in the Safavid-Qizilbash Sufi order, perhaps even that of the khalifat al-khulafä. Among the high-ranking Qizilbash in the sixteenth and seventeenth centuries, I have identified three persons who were both sayyid and bore the name "Abd al-Bāqī" or "Bāqī." One was a certain Sayyid Bāqī who wrote a letter to Sayyid Yusuf soon after Shah 'Abbas I's conquest of Baghdad in 1624. ${ }^{61}$ As 'Abd al-Bāqī Efendi's letter seems to have been written in the sixteenth century, it is unlikely that he was the same person as Sayyid Bāqī. ${ }^{62}$ Another person named Amir Sayyid Sharif Bāqī was appointed the commander, the shaykh al-Islam, and the khalifat al-khulafa of the Province of Fars by Shah Tahmasb in $1548 .{ }^{63}$ The last person I could identify was Sayyid 'Abd al-Bāqī, who was the vakil al-saltanah or the alter ego of Shah Ismail I and died in the Battle of Chaldiran in $1514 .{ }^{64}$ As I discussed in the first part of this paper, the anticipation of Shah Ismail's march on Anatolia was widespread among the Anatolian Qizilbash before the Battle of Chaldiran. It is most likely that the good tidings mentioned at the beginning of 'Abd al-Bāqī Efendi's letter referred to this anticipation. Therefore, we may conclude, with caution, that this person could have been Shah Ismail's vakìl al-salțanah Sayyid 'Abd al-Bāqī.

The letter's audience is described as "the lovers of the House of Muhammad 'Alī," "lovers of the Pole of the Saints and the King of the most pious ones (Quţ al-Awliya wa-Sultān al-Atqiy $\bar{a}$ ) [Shaykh Șafi]]," "brothers who are sincere practitioners of the ritual," "disciples who reside in corners of villages and towns," "holy warriors and princes (beg) whose heart's eyes always look at this Sublime Lodge," and "adherents who long for seeing the beautiful face [of the Shah] (mushtāq-e dìdār).” After addressing his audience as such, 'Abd al-Bāqī moves to his main subject matter with the following reminder: "You must attach yourselves to the skirt of Muhammad 'Ali to the best of your ability ... remove heedlessness from your eyes and hearts." The rest of the letter provides a concise description of the basic rituals and principles of the Qizilbash Path. In other words, it is essentially a summary account of the Buyruk. ${ }^{65}$ It begins with an admonition to disciples to grow diligent in observing the rituals of the

\footnotetext{
${ }^{60}$ Yıldırım, "Literary Foundations," 76-87. For an extensive discussion of the formation of the "canonical" Buyruk text and a critical edition of the Shah Tahmasb Vulgate, see Yıldırım, Menâkıb-ı Eliyâ (Buyruk).

${ }^{61}$ For a detailed discussion of this letter, see below.

${ }^{62}$ Afyer Karakaya-Stump suggests without providing evidence that the authors of these two letters must have been the same person. See Karakaya-Stump, "Subjects of the Sultan," 202-3.

${ }^{63}$ Horst, "Zwei Erlasse," 307-8.

${ }^{64}$ Yildirim, "Turkomans," 628.
} 
Path, following the orders of their spiritual master, and fulfilling responsibilities owed to their musăḩib. ${ }^{66}$ Then it provides a brief explanation concerning the requirements of the covenant of the musābib and the responsibilities of brothers to each other. This short section ends with the warning that "They [the disciples] should not remain without murabbi and muṣạhib in this community so that they not be deprived of witnessing the faces of the Saints on the Day of Judgment."

In the next section, 'Abd al-Bāqi summarizes the attributes of the rightful shaykhs on the Path and exhorts aspirants to be careful about false spiritual masters, whose basic characteristics are also listed. According to the text, one of the worst sins is to disclose the secrets of the tariqab to ordinary people. 'Abd al-Bāqi states that if a person discloses the secrets of the tariqah to strangers for whatever reason, be it heedlessness, worldly benefits, or surrendering to the desires of their lower soul, their murder is lawful. As can be noticed immediately, the rule of secrecy was deemed an article of the faith. It appears that this became part of a survival strategy of the Qizilbash-Alevis due to the extreme persecutions they were subjected to under Ottoman rule.

'Abd al-Bāqi then goes on to describe the essential attributes of a rightful guide. Quoting from Shaykh Sayyid Șafī, he states that a person does not deserve to be a murabbi unless he is able to take his aspirant from the darkness of ignorance to enlightenment and to save his faith from the delusions of Satan. A perfect guide is a person who cleanses the mirror (of the heart) of the aspirant, makes it untainted, solves all his problems on the Path, and guides him to the Truth.

Another theme dominating the entire letter is the regulations concerning the institution of the mușạhib. Attaching oneself to a murabbi and having a mușăhib are repeatedly underscored as the two essentials of the Path. 'Abd al-Bāqi admonishes his Qizilbash audience: "If a person does not pledge allegiance to a perfect murabbi and does not attain a musāhib in accordance with the tradition of Muhammad 'Alī, what he eats and drinks are all unlawful." But the requirements of the musăhib covenant are not easy to fulfill. First of all, they must observe the rituals and obligations of the Path; if one of them goes astray, then his covenant becomes void. Once they become musăḅib on the Path, they have to cooperate and help each other under all circumstances. "Mușähibs must share their problems and never abstain from helping one another. If a mușăhib keeps secrets from his brother, according to the ruling of the Shaykhs, he is no longer a musähib; rather, by the ruling of the Guide, he is expelled from the Path."

\footnotetext{
${ }^{65}$ Observing this quality of the letter, Abdülbaki Gölpınarlı called it the "Little Buyruk," a term which does not appear in the buyruk manuscripts. See Gölpınarl, Tarih Boyunca, 178.

${ }^{66}$ Musăbibib is one of the fundamental institutions of the Safavid-Qizilbash Sufi order. According to the rules of the tariqah, as explained in the Buyruk, every member of the community must attain a musăhaib when they reach the age of maturity, usually soon after marriage. Attaining a musähip signifies becoming a full member of the Qizilbash-Alevi faith community. The two believers, together with their wives, become musăhib through a special ritual of initiation presided over by their spiritual guide (variously called murebbi, murshid, or pir). Once bound together with the covenant of musăhaib, the two path brothers and their wives are supposed to share everything in the Path, including worldly possessions, spiritual positions, responsibilities, and sins.
} 
After this letter comes the last section of the Buyruk, which is a brief explanation of the nature of the knowledge written in it and the proper precept and rituals of reading the Buyruk:

Now, we have written the precepts, rituals, and principles of the Saints (Arkan-e Awliy $\bar{a})$ in this book so that aspirants who are lovers of the Saints may read it and act accordingly. And whenever they read it, may they not forget this poor soul's name in their prayers. Even if a person's lifespan is as long as that of the Prophet Noah, he cannot write down this Manāqib-e Sharif in its entirety. This is because Manāqib-e Awliya and the science of esoteric knowledge have no limits. We wrote such a small portion of it merely to guide the disciples (tálibs). It is incumbent on the eve of Friday upon every shaykh, khalifah, and pir to light a candle and serve food, to the best of their ability, for the purpose of attaining God's consent and pleasing the spirits of Muhammad 'Alī, the Twelve Imams, the Fourteen Impeccables, deceased ancestors, spiritual masters, and his parents. After the banquet, they should read this Manaqib of the Saints so that the aspirants and the lovers hear it. It is imperative, in turn, that the aspirants and the lovers (muhibb) listen to it very carefully-as one must learn what one does not know -and practice the rituals and the precepts explained in this Book of Manäqib to the best of their abilities. Be warned that the People of the Ritual (erkân erenleri) should not read this Manäqib-e Sharif in the presence of ordinary people and should not give it to unqualified persons. Rather, it is meant to be read by the lovers of the Saints (evliya mubibleri) alone.

Its content clearly shows that this was not an ordinary letter simply carrying news, but a religious text intended to convey sacred knowledge of the Path. It was penned to train disciples on the etiquette, rituals, and regulations of the Safavid-Qizilbash tariqah. And it must have been because of that the letter was later included in the canonical sacred book of the Qizilbash-Alevis.

The second letter I will examine has been preserved by Dede Garkın ocak, an important Alevi murshid family in Turkey. It is one of the few extant historical sources documenting the formation of ocak families as well as the relationship between the Alevi ocaks and the Safavid shahs. The letter was written in Turkish and sent by a certain Sayyid Bāqī in Iran to Sayyid Yusuf in Anatolia, then the head of Dede Garkın family. ${ }^{67}$

In the introduction to the letter, Sayyid Bāqi makes a clear reference to Shah 'Abbas I. After addressing Sayyid Yusuf with honorific titles such as the "exalted shelter of sayyidhood," the "holder of dignity," the "son of Dede Garkın the Elected Saint

\footnotetext{
${ }^{67}$ The original document is currently in the private library of Galip Dedekarginoğlu in Istanbul. A transliterated Turkish text, along with a facsimile copy of this document, is published in KarakayaStump, "Kızlbaş, Bektaşi, Safevi." The facsimile copy of the document in Karakaya-Stump's publication is not readable. For this study, I have obtained from its owner a better picture of the original document, which is included in Appendix 2.
} 
(budalā) of the Truth," and "my beloved son and the light of my eyes," Sayyid Bāqī gives a brief explanation of his own state of being. He says, "He was in a felicitous mood in the Sublime Lodge (Dargäh-e ' $\bar{A} l \bar{i})$, which was like the Threshold (asitāne) of the Nest of Angels since it possessed the desire-bestowing dust of the feet of the Shah and he was praying for the continuity of the lifespan and rule of the Shah." Although the name of the shah is not written in the document, the context reveals that he was Shah 'Abbas the Great. He is referred to as the "possessor of the religion and the world," "the enlightener of the Path of the Saints," "the kernel of the offspring of the People of the Cloak," and "the desire-bestower of the party of 'Alī al-Murtaḍa." Then Sayyid Bāqī states:

O my sons, the commander of the gallants of the battlefield, for whom you enlightened ones (erenler) have been waiting so long in patience, has arisen to bestow the wishes of the lovers of the House [of the Prophet] and to expunge the progeny of the enemies of the Prophet's Family on earth. On the twenty-second of Rabit alAwwal he captured the citadel of Baghdad in one day. Coins have been minted and the Friday sermons have been read in his name. By the will of God, his intention is to march on Anatolia. We appeal to the Divine Court (Dargāh-e Haqq) that this would be achieved soon.

The above passage demonstrates that the letter was written shortly after the Safavid conquest of Baghdad. We know that the Safavids captured the city of Baghdad twice, first by Shah Ismail on 20 Jamādhī II, 914 (16 October 1508) and the second by Shah

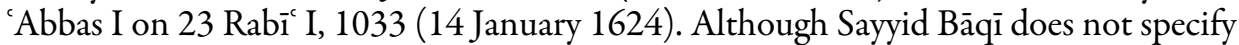
the year, the day of conquest that he records agrees with the date of the second conquest by Shah 'Abbas I. Furthermore, as we know, the first conquest of Baghdad was actually achieved by Husayn Beg Lala, Shah Ismail being invited only after the Qizilbash took control of the city. Therefore, one may surmise that the letter was written after Shah 'Abbas the Great's conquest of Baghdad. ${ }^{68}$

Sayyid Bāqi describes himself as the "slave of the King of the Sainthood" (bandab-ye Shäh-e Walayat) and the "son of the Pole of the Gnostics (awläd-e Qutb al-'Arifiñ) Sulțān Hācī Bektāsh (?) Walī.” According to Ayfer Karakaya-Stump, Sayyid Bāqī was a shaykh in one of the Bektashi lodges in Iraq. Therefore, this document proves Sayyid Yusufs adherence to the Bektashi Sufi Order. ${ }^{69}$ However, my analysis of the document concludes otherwise. First of all, although the words "Sultān Hācī" and "Walī" are clearly legible, the word "Bektāsh" is not very clear since the document is slightly damaged in this part. Secondly, even if we read this name as Bektāsh, the way it is inserted in the document invites suspicion about its authenticity. The main body of the signature reads "Bandah-ye Shäh-e Waläyat, Awläd-e Qutb al-'Arifiñ." Right below this formulaic phrase lies a stamped seal, which unfortunately cannot be

\footnotetext{
${ }^{68}$ See Monshi, History, I, 55-6; II, 1226. Karakaya-Stump arrives at the same conclusion. See Karakaya-Stump, "Kızılbaş, Bektaşi, Safevi," 119-20.

${ }^{69}$ Karakaya-Stump, "Kızılbaş, Bektaşi, Safevi," 120-3.
} 
read. ${ }^{70}$ The phrase "Sulțān Hāāì Bektāsh (?) Walī" is inscribed above the whole signature complex. One suspects that this phrase was a later addition to the document. Probably it was inserted on top of the whole signature complex because there was not enough space between the original signature phrase and the seal. If we adopt such an interpretation, the honorific title "Shāb-e Walayat" likely refers to Imam "Alī Ibn Abì Ṭālib and "Quṭb al-Árifin" to Shah 'Abbas the Great. Since the term "awläd (Turkish evläd, i.e., sons)" is commonly used in the Safavid-Qizilbash tariqah for disciples (tälib) with reference to their spiritual guides (murshid or murabbì), we can then conclude that Sayyid Bāqi defined himself as the disciple of Shah 'Abbas.

Even if we accept that the phrase "Hācī Bektāsh Walī" is a genuine part of the original document, we cannot interpret this as a proof of an institutional relationship between the letter and the Bektashi Sufi order. The content of the letter has no sign of affiliation to the Bektashi Sufi order whatsoever. Its language, terminology, and style are completely different from the diplomas that were issued in the central Bektashi lodge in Kırşehir. ${ }^{71}$ Furthermore, the existence of Bektashi lodges in Iraq at that time is not corroborated by sources. ${ }^{72}$ In the meantime, the terminology, key concepts, and fundamental institutions, such as murabbi and musăḅib, referred to in the letter reflect exclusive Qizilbash provenance. As I will discuss shortly, the second half of the letter looks like an excerpt from the Buyruk. Therefore, even if Sayyid Bāqi was a descendant of Hācī Bektāsh, he was not a Bektashi shaykh but a Qizilbash khalïfah, if not the khalīfat al-khulafā. I would suggest hence that this letter is a genuine Qizilbash document that was issued by the office of the khaliffat al-khulafā.

This argument is corroborated by oral traditions among the family members of the Dede Garkın ocak. The document has been known by the family members as "berāt," that is, the document that legitimizes their spiritual authority as a Qizilbash-Alevi ocak on their tälib groups. Although several branches of Dede Garkın ocak have kept a number of other documents, including diplomas of sayyid pedigree (siyādatnāmah) and diplomas of Sufi qualification (ijäzatnamah) dating from the fifteenth and the sixteenth centuries, this document has been held the most esteemed among others and has always been kept in possession of the head of the ocak. ${ }^{73}$ Oral traditions maintain that Sayyid Yusuf, also known as Sultan Yusuf, is considered as the second founder of the ocak, after the eponymous founder Nu'mān Dede Garkın, who was the spiritual master of Baba Ilyas (d. 1240), the famous mystic leader of the Babai upheaval against the Anatolian Seljukid rule. ${ }^{74}$ For that reason, members of Dede Garkın ocak

\footnotetext{
${ }^{70}$ This might well be the official seal of the khalifat al-khulafä. Nonetheless, the fact that it is illegible prevents us from concrete conclusions on this issue.

${ }^{71}$ For a content and stylistic analysis of the standard Bektaşi ijäzat-nāme, see Yıldırım, "Bektaşi Kime Derler?”; Yıldırım, Bektaşiliğin Doğuşu, 275-6, 304-12.

${ }^{72}$ Karakaya-Stump, "Irak'taki Bektaşi Tekkeleri," 694, 697, 713-15. Karakaya-Stump rightfully notices that the earliest explicit references to the existence of Bektaşi lodges in Iraq trace back to the mid-eighteenth century. Understandably, diplomas that were granted to Alevi dedes from the Karbala Lodge henceforth follow the standard Bektaşi style. See ibid, 701, 713-14.

${ }^{73}$ Most of those documents, except this letter, are published in Ocak, Ortaçăg Anadolu'sunda.
} 
also call themselves the "sons of Sultan Yusuf (Sultan Yusuf evlatlart)." Members and taalibs of Dede Garkın ocak still pay ritual visits to Sayyid Yusuf s tomb in Malatya in eastern Anatolia as they consider the tomb a sacred place. Meanwhile, members of Dede Garkin ocak reject any affiliation with the Bektashi Sufi order. ${ }^{75}$

A diploma of Sufi qualification (ijäzatnämah) preserved by another branch of Dede Garkın ocak suggests that Sayyid Yusuf had already attained the post of spiritual guidance in 1588 and was living in the village of Bīmāre in the province of Malatya. The document was issued by the Naqīb al-Ashräf of Karbala in Muharram 997 (November/December 1588). It certifies that after paying proper ritual visits to the tombs of the Imams in Baghdad, the tomb of Imam 'Áli in Najaf, and the shrine of Imam Husayn in Karbala, Sayyid Yusuf bin Qādī Shaykh was invested with the authority of spiritual guidance. ${ }^{76}$

We may conclude, hence, that the letter was sent by a high-ranking Qizilbash khaliffah, most probably the khalifat al-khulafä, to a leading member of Dede Garkın family that had a long Sufi pedigree tracing back to medieval Anatolia. It becomes even more explicit in the main body of the text that the letter was issued by the office of the khalifat al-khulafā in Iran on the authority of the shah in his capacity of the Perfect Guide of the Safavid-Qizilbash Sufi order (tariqah). It refers to a shajarah or khiläfat-nāmah that authorized Sayyid Yusuf as a khaliffah on the Path. It is also stated that Sayyid Yusuf and his tălibs were recorded in the "Register" in the Sublime Lodge according to the list that the latter's messenger brought.

After giving the good tidings of the shah's victory and intention to march on Anatolia, Sayyid Bāqī proceeds to the subject matter as follows:

And now, you should know that Sevinduk Sufi, to whom we gave this letter [to deliver to you], came to this Sublime Lodge (Dargāh-e 'Álī) and arrived at the desire-bestowing dust of the feet of the Perfect Guide (Murshid-e Kämil); his ritual visit and submissive desire (niyzaz) was accepted. In the same vein, you enlightened ones' (siz erenlerin) sincere adherence to and proper observance of [the rituals of the Path] were presented in the Sublime Lodge. Subsequently you were given our blessing by way of adding "Shah" to your name. Then Sevinduk Sufi delivered your pledge of allegiance in the presence of the ghazis who are the people of divine unity (ahl-e tevbid ghäziler) to this humble man who prays for you (dúācını) [Sayyid $B \bar{q} \bar{i} \overline{1}$. And we accepted your pledge of allegiance, enacted the proper ritual of the enlightened ones (erenler), and admitted your sacrifice (tercümān). In accordance

\footnotetext{
${ }^{74}$ For the major primary source about Dede Garkın, see Elvan Çelebi, Menâkıbu'l-Kudsiyye.

${ }^{75}$ From my interviews with Hüseyin Dedekargınoğlu, who is the acting dede of Dede Garkın ocak, on 8 January 2019 and 27 June 2019. Poems of several Garkın-affiliated Alevi poets lived in the eighteenth, nineteenth, and early twentieth centuries, which praise Sultan Yusuf as one of the greatest shaykhs of the ocak, also demonstrate the important place of Sayyid (Sultan) Yusuf in the history of Dede Garkın ocak. See Dedekargınoğlu, Aşılkların Dilinden, 73-4.

${ }^{76} \mathrm{~A}$ transliteration of the ijäzatnämah with its facsimile copy is published in Ocak, Ortaçăg Anadolu'sunda, 255-65. Ayfer Karakaya-Stump's claim that this document was issued in a Bektashi lodge in Karbala is not substantiated by the available sources. See Karakaya-Stump, “Kızılbaş, Bektaşi, Safevi,” 121.
} 
with the divine order "they but pledged allegiance to God and His Apostle,"77 your hand reached to the People of the House of the Apostle of God and you joined those whose heads are elevated in this world and in the next. Your name is recorded in the Register (defter) and you became one of those people who have been granted a headgear [the special scarlet turban of the Qizilbash] (sikke-zadah). By the will of God, we will issue a shajarah in your name that proves your office of khiläfat over the ghazzis and the community (jamã $a b)$ who had been attached to you[r family]. If it is possible for you to come and see us here, we will deliver it [the shajarab] personally; otherwise, we will send it with a trustworthy faithful brother to your province. Sevinduk Sufi has already delivered us the exact list of the ghäzis who are among devotees of you enlightened ones' ocak (siz erenlerin ocăğna muhibb olan). This being said, keep your trust in this humble man who prays for you [Sayyid Bāqī] and have confidence that this will be taken care of! And know that from this day onward, we accept you the enlightened one as a sincere adherent of this Path; [in the same vein,] let it be known that those brothers who pledge their allegiance to you are accepted in this Sublime Lodge. ${ }^{78}$

This long excerpt constitutes the single most informative account regarding the ritual procedure of khalifah investiture in the Safavid-Qizilbash Sufi order. Neither the extant shajarahs nor any other Safavid sources mention the ritual of investiture. In this case, the ritual was performed in the absence of the invested khalifah. One would safely surmise, however, that the ordinary ritual of investiture should be no different. The document also provides strong evidence from inside the QizilbashAlevi community for the endurance of strong ties between the Ottoman QizilbashAlevis and the Safavid shahs in the seventeenth century.

The rest of the letter is a concise summary of the essentials of the Safavid-Qizilbash Path. It discusses the importance of attaching oneself to a spiritual guide (murabbi) and to a musāhib; it warns of the necessity of the prudent observation of rituals and of avoiding prohibitions. This second half of the letter starts with the admonition, "And after this day, my sons, you should not compare this time with other times. You shall leave heedlessness aside, open the eyes of your heart, walk on the Path with the murabbi and the musăhib, observe the rituals of the Saints!" After underscoring the importance of attaining the consent of the Perfect Guide and following his words, which constitute the life-giving guidelines of the tariqah, the letter continues with a brief explanation regarding the qualifications and responsibilities of the spiritual guide and the musanhib. It is stated here that a person who claims to be pir or murabbi must have such a degree of esoteric knowledge that they must be able to guide the tălib from the darkness of ignorance to the light. A murabbi becomes a real murshid only when he is able to save his disciple's faith from Satan's delusion. He must also be able to solve problems of his disciples on the Path. For the musăhaib, the first prerequisite is to follow the Path in accordance with the ruling of

\footnotetext{
${ }^{77}$ The Quran, 48:10.

${ }^{78}$ See Appendix 2. Also compare with Karakaya-Stump, “Kızılbaş, Bektaşi, Safevi,” 125-6.
} 
the Saints. The letter ends with the admonition, "Now, o brothers who have attached themselves to the Ocak of the House (Hänedān Ocăgı)! You shall attach yourselves to a rightful spiritual guide ( $p i r)$, achieve esoteric knowledge, and attain maturity so that you not remain stuck in the stage of ignorance!"

Just like the above-mentioned letter of 'Abd al-Bāqī Efendi, this letter has a significant didactic aspect, even though it was written primarily to inform Seyyid Yusuf about the admittance of his earlier application for khiläfat. These two surviving letters shed significant light on the ways in which the Safavid dynasty maintained its connection with the Anatolian Qizilbash-Alevis. These Alevi sources, alongside the other archival evidence, demonstrate that messengers and khalifabs went back and forth between Ottoman provinces and Iran despite the extreme persecution by the Ottoman government. We also learn from these documents that didactic letters that were issued by the office of the khalifat al-khulafa functioned as vehicles of religious propaganda and indoctrination. One may assume that there was a special division under the office of khalifat al-khulafa dealing with the affairs of disciples residing in Ottoman territories. Unfortunately, the scarcity of sources from the Safavid side does not allow us to corroborate this assumption.

\section{Conclusion}

The goal of this study is to introduce a relatively unknown part of Ottoman and Safavid history. It aims to unveil a critical period of Qizilbash-Alevi history which has received little attention on the part of scholars. Challenging the prevailing premises of the available Ottoman and Safavid historiographies, which draw an artificial line between the Qizilbash, who founded and ruled the Safavid state, and the Alevis, who lived in Anatolia and the Balkans, I have argued that they were one and the same socioreligious community. Although the political allegiance of the Anatolian Qizilbash to the Safavid state was undermined after the Chaldiran defeat in 1514, their religious adherence to the Safavid-Qizilbash tariqah, which I call the "Safavid-Qizilbash ecumene," lasted until the end of the Safavid dynasty in the mid-eighteenth century. It is true that by the early decades of the sixteenth century the Anatolian Qizilbash found themselves compelled to retreat into isolated socioreligious enclaves within the hegemonic Ottoman Sunni world. However, this new situation only stripped the Qizilbash-Alevi identity of its politico-military character, but not its religious connection with the Safavid-Qizilbash tariqah. My examination of the sources showed that during this period of roughly two centuries, the Safavid shahs continued to be the murshid-e kamil of the Anatolian Qizilbash. Likewise, the latter were members of the Safavid-Qizilbash tariqah just like the military elite of the Safavid state.

Another major goal of this study was to examine the internal socioreligious structure and belief system of the Qizilbash-Alevi community. Scholarship to date remains silent about the internal history of the Qizilbash, both in Safavid and Ottoman territories. This is mostly because of the nature of sources on which these two bodies of scholarship rely. Strikingly, on the one hand, the Qizilbash military elites who 
ruled Iran for almost two centuries left no written sources that have survived to the present day. On the other hand, their brothers and sisters in Ottoman Anatolia and the Balkans, who were suppressed and persecuted by the Ottoman state, managed to preserve some written sources of Qizilbash provenance. These sources were unknown until recently, as the Alevi community kept them secret.

Recent studies undertaken among Alevi communities have unearthed a substantial collection of documents and manuscripts. Nevertheless, because of the above-mentioned view of the Qizilbash in scholarship, this written heritage of the Alevis was not used as a source for the Safavid-Qizilbash ecumene, even after they were discovered. In this study, I have approached these documents and manuscripts as internal sources of the Qizilbash community. I have argued that a reevaluation of conventional sources in light of recently discovered Alevi manuscripts and documents provides insight into the history of not only the Qizilbash-Alevis but also the military caste of the Safavid empire. From this perspective, I drew a preliminary picture of the socioreligious organization and religious beliefs and practices of the Qizilbash-Alevi community in the sixteenth and seventeenth centuries. This study also demonstrated that these newly discovered Alevi sources possess the potential to contribute to the history of the Qizilbash in Iran. Therefore, further studies on these sources, as well as the unearthing of new sources of similar provenance, may open up a new avenue of inquiry into Safavid historiography.

\section{Bibliography}

Ardakānī, Majīd Hāshimī and Husayn Mīr-Ja farī. "Farmān-e Shāh Ṭahmāsb-e Ṣafawī bih Mawlānā Raḍi al-Dīn Muhammad dar mawrid-e intișāb-e vey bih khilāfat-e qismatī az manțiqah-ye Fārs (Ardakān, Mamassanī, Kūh-e Gīlūyeh)." Barassīhā-yi Tärīkhī 2 (1353): 97-106.

Aşıkpaşazâde. Tevârib-i Âl-i Osman, in Osmanlı Taribleri. Ed. Nihal Atsız. İstanbul: Türkiye Yayınevi, 1949.

Aubin, Jean. "Études Safavides I, Šah Ismail et les notables de l'Iraq persan." Journal of Economic and Social History of the Orient 2, no. 1 (1959): 37-81.

Aubin, Jean. "L'avènement des Safavides reconsideré (Études Safavides III)." Moyen Orient \& Océan Indien 5 (1988): 1-130.

Aubin, Jean. "Revolution chiite et conservatisme. Les soufis de Lāhejān, 1500-1514 (Études Safavides II)." Moyen Orient \& Océan Indien 1 (1984): 1-40.

Aytaş, Gıyasettin. Belgeler Iş̆ğında Şah İbrahim Veli Ocăğ. Ankara: Gazi Üniversitesi Türk Kültürü ve Hacı Bektaş Veli Araştırma Merkezi Yayınları, 2011.

Bacqué-Grammont, Jean-Louis. Les ottomans, les Safavides et leurs voisins. Istanbul: Nederlands Historisch-Archaeologisch Instituut te Istanbul, 1987.

Baltacioğlu-Brammer, Ayşe. "The Formation of Kizilbas Communities in Anatolia and Ottoman Responses, 1450s-1630s." International Journal of Turkish Studies 20, no. 1\&2 (2014): 21-47.

Bisâtî. Şeyh Sâfî Buyruğu (Menâkıbu'l-Esrâr Behcetül-Ahrâr). Ed. Ahmet Taşğın. Ankara: Rheda-Wiedenbrück Çevresi Alevi Kültür Derneği Yayınları, 2003.

Bitlisî, İdrîs. Selim Şah-nâme. Ed. Hicabi Kırlangıç. Ankara: Kültür Bakanlı̆̆ı Yayınları, 2001.

Celâl-zâde Mustafa. Selim-nâme. Ed. Ahmet Uğur and Mustafa Çuhadar. İstanbul: Milli Eğitim Bakanlığı Yayınları, 1997.

Çıpa, H.E. The Making of Selim: Succession, Legitimacy, and Memory in the Early Modern Ottoman World. Bloomington: Indiana University Press, 2017. 
Danon, M.A. "Un interrogatoire d'hérétiques musulmans (1619)." Journal Asiatique (April-June 1921): 281-93.

Dedekargınoğlu, Hüseyin. Asşsların Dilinden Dede Garkın. Ankara: Yurt Kitap-Yayın, 2015.

DeWeese, Devin. "Foreword." In Mehmed Fuad Köprülü, Early Mystics in Turkish Literature, trans. and ed. Gary Leiser and Robert Dankoff, viii-xxvii. London: Routledge, 2006.

Dihgan, Ibrahim. "Farmān-e Khalīfat al-Khulafā-ye Sayyid Ibrāhīm az Shāh Sulțān Husayn-e Ṣafawī." Rāhnamā-yi Kitāb III-IV (1348): 179-81.

Dressler, Markus. Writing Religion: The Making of Turkish Alevi Islam. Oxford: Oxford University Press, 2013.

Elvan Çelebi. Menâkıbu'l-Kudsiyye fî Menâsibi'l-Ünsiyye. Ed. İsmail E. Erünsal and Ahmet Y. Ocak. Ankara: Türk Tarih Kurumu Yayınları, 1995.

Floor, Willem. "The Khalifeh al-kholafa of the Safavid Sufi Order." Zeitschrift der Deutschen Morgenländischen Gesellschaft 153, no. 1 (2003): 51-86.

Gelibolulu Mustafa 'Âli. Kitabu't-Tarih-i Künhü'l-Abbar. Ed. A. Uğur, M. Çuhadar, A. Gül, and İ. H. Çuhadar. Kayseri: Erciyes Üniversitesi Yayınları, 1997.

Gölpınarlı, Abdülbaki. "İslâm ve Türk İllerinde Fütüvvet Teşkilâtı ve Kaynakları." İstanbul Üniversitesi Íktisat Fakültesi Mecmuası 11, no. 1-4 (1949-50): 3-354.

Gölpınarlı, Abdülbaki. Tarih Boyunca İslâm Mezhepleri ve Sî̀ilik. İstanbul: Der Yayınları, 1987.

Grey, Charles, ed. and trans. A Narrative of Italian Travels in Persia in the Fifteenth and Sixteenth Centuries. London: Hakluyt Society, 1873.

Hammer, P. J. Büyük Osmanlı Taribi, vol. II. Trans. Mehmet Ata. Ed. Mümin Çevik and Erol Kılıç. İstanbul: Üçdal Neşriyat, 1984.

Haneda, Masashi. Le Châh et les Qizilbâs: Le système militaire safavide. Berlin: Klaus Schwarz Verlag, 1987.

Hinz, Walter. Irans Aufstieg zum Nationalstaat im fünfzehnten Jahrhundert. Berlin: Walter de Gruyter \& Co, 1936.

Hoca Sadettin Efendi. Tacü’t-Tevarih, vol. IV. Ed. İsmet Parmaksızoğlu. Ankara: Kültür Bakanlığı Yayınlar1, 1999.

Hoca Sadettin Efendi. Tacü’t-Tevarih, vol. III. Ed. İsmet Parmaksızoğlu. Ankara: Kültür Bakanlığı Yayınları, 1999.

Horst, Heribert. "Zwei Erlasse Šāh Tahmāsps I." Zeitschrift Der Deutschen Morgenländischen Gesellschaft 110, no. 2 (1960): 301-9.

Imber, Colin H. "The Persecution of the Ottoman Shi ites According to the Mühimme Defterleri, 15651585." Der Islam 56, no. 2 (1979): 245-73.

Kaplan, Doğan. "Buyruklara Göre Kızılbaşlık." PhD diss., Selçuk University, Konya, 2008.

Kaplan, Doğan. Erkânnâme 1. Ankara: Türkiye Diyanet Vakf̧, 2007.

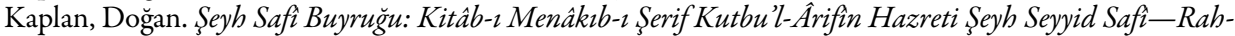
metullâbi Aleyh-(17. Yüzyzl). Ankara: Türkiye Diyanet Vakfi, 2015.

Kaplan, Doğan. Yazılı Kaynaklarna Göre Alevilik. Ankara: Türkiye Diyanet Vakfi, 2010.

Karakaya-Stump, Ayfer. "Alevi Dede Ailelerine Ait Buyruk Mecmuaları.” In Eski Türk Edebiyatı Çalı̧̧maları VII: Mecmua: Osmanlı Edebiyatının Kırkambarı, ed. Hatice Aynur, Müjgân Çakır, Hanife Korucu, Selim S. Kuru, and Ali Emre Özyldırım, 361-79. İstanbul: Turkuaz Yayınları, 2012.

Karakaya-Stump, Ayfer. "Documents and Buyruk Manuscripts in the Private Archives of Alevi Dede Families: An Overview." Journal of Middle Eastern Studies 37, no. 3 (2010): 273-86.

Karakaya-Stump, Ayfer. "Irak'taki Bektaşi Tekkeleri.” Belleten 71, no. 261 (2007): 689-720.

Karakaya-Stump, Ayfer. "Kızılbaş, Bektaşi, Safevi İlişkilerine Dair 17. Yüzyıldan Yeni Bir Belge.” Journal of Turkish Studies / Türklük Bilgisi Araștırmaları 30, no. 2 (2006): 117-30.

Karakaya-Stump, Ayfer. "Subjects of the Sultan, Disciples of the Shah: Formation and Transformation of the Kizilbash/Alevi Communities in Ottoman Anatolia." PhD diss., Harvard University, 2008.

Karakaya-Stump, Ayfer. "The Vefă’iyye, the Bektaşiyye and Genealogies of 'Heterodox' Islam in Anatolia: Rethinking the Köprülü Paradigm.” Turcica 44 (2012-13): 279-300.

Karakaya-Stump, Ayfer. Vefailik, Bektaşilik, Kızılbaşlık: Alevi Kaynakların, Taribini ve Tarihyazımın Yeniden Düsünmek. İstanbul: Bilgi Üniversitesi Yayınları, 2015. 
Karamustafa, A.T. "Yesevlik, Melâmetîlik, Kalenderîlik, Vefâilik ve Anadolu Tasavvufunun Kökenleri Sorunu." In Osmanl Toplumunda Tasavvuf ve Sufiler, ed. Ahmet Yaşar Ocak, 61-88. Ankara: Türk Tarih Kurumu, 2005.

Karamustafa, A. T. "Kaygusuz Abdal: A Medieval Turkish Saint and the Formation of Vernacular Islam in Anatolia." In Unity and Diversity: Mysticism, Messianism and the Construction of Religious Authority in Islam, ed. Orhan Mir-Kasimov, 329-2. Leiden: Brill, 2014.

Kemalpaşazâde. Tevârih-i All-i Osman, Defter VIII. Published by Ahmet Uğur in his The Reign of Sultan Selim I in the Light of the Selim-name Literature. Berlin: Klaus Schwarz Verlag, 1985.

Kemalpaşazâde. Tevârih-i Al-i Osman, VIII: Defter. Ed. Ahmet Uguru. Ankara: TTK, 1997.

Köprülü, Fuad. "Ahmet Yesevi." İslâm Ansiklopedisi, vol. I (1940): 210-15.

Köprülü, Fuad. “Anadolu'da İslamiyet: Türk İstîlâsından Sonra Anadolu Tarih-i Dînîsine bir Nazar ve Tarihinin Menba'ları.” Dârülfünûn Edebiyat Fakültesi Mecmuası 4 (Eylül 1338/1922): 281-311; 5 (Eylül 1338/1922): 385-420; 6 (Mart 1339/1923): 457-86.

Köprülü, Fuad. "Bektaş, Hacı Bektaş.” İslâm Ansiklopedisi, vol. II (1940): 461.

Köprülü, Fuad. "Bektaşîiğin Menşe’leri: Küçük Asya'da İslam Batıniliğinin Tekamül-i Tarihiyyesi Hakkında Bir Tecrübe." Türk Yurdu 2, no. 8 (1341/1925): 121-40.

Köprülü, Fuad. Influence du chamanisme turco-mongol sur les ordres mystiques musulmans. Istanbul: Imp. Zellitch Frères, 1929.

Köprülü, Fuad. Türk Edebiyatında İlk Mutasavviflar. İstanbul: Matbaa-yı Âmire, 1918.

Kreutel, R.F., ed. Haniwaldanus Anonimine Göre Sultan Bayezid-i Velî (1481-1512). Trans. Necdet Öztürk. İstanbul: Türk Dünyası Araştırmaları Vakfi, 1997.

Mazzaoui, M.M. "The Ghāzī Backgrounds of the Safavid State." Iqbäl Review 12, no. 3 (1971): 79-90.

Mazzaoui, M.M. The Origins of the Safawids: Shi ism, Sufism, and the Ghulat. Wiesbaden: Franz Steiner Verlag, 1972.

Mélikoff, Irène. "L'Islam hétérodoxe en Anatolie." Turcica XIV (1982): 142-54.

Mélikoff, Irène. Au banquet des quarante. Exploration au coeur du Bektachisme-Alevisme. Istanbul: ISIS Press, 2001.

Mélikoff, Irène. De l'épopée au mythe. Itinéraire turcologique. Istanbul: ISIS Press, 1995.

Mélikoff, Irène. Sur les traces du soufisme turc. Recherches sur l'Islam populaire en Anatolie. Istanbul: ISIS Press, 1992.

Membré, Michele. Mission to the Lord Sophy of Persia (1539-1542). Trans. with intro. and notes A.H. Morton. London: School of Oriental and African Studies, 1993.

Minorsky, Vladimir, trans. Tadhkirat al-Muluk. A Manual of Safavid Administration. Gibb Memorial Series, XVI. London: Luzac \& Co., 1943.

Minorsky, Vladimir. "The Poetry of Shah Ismail I." Bulletin of the School of Oriental and African Studies X (1938-42): 1006a-1053a.

Monshi, Iskandar Beg. History of Shah 'Abbas the Great, 2 vols. Trans. Roger M. Savory. Boulder, CO: Westview Press, 1978.

Morton. A.H. "The Chüb-i Tarìq and Qizilbāsh Ritual in Safavid Persia." In Études Safavides, ed. Jean Calmard, 225-44. Paris: Institut Français de Recherche en Iran, 1993.

Müneccimbaşı Ahmed Dede. Sahâif-ül-Ahbâr fî Vekâyi-ül-âsâr. Trans. and ed. İsmail Erünsal. N.p.: Tercüman 1001 Eser Serisi, n.d.

Musavi, M.T. Orta asr Azarbaijan tarikhina dair fars-dilli sanadlar (XVI-XVIII asrlar). Baku: Elm, 1977.

Nikitine, Basil. "Essai d'Analyse du Safwat as-Safa." Journal Asiatique 245 (1957): 385-94.

Ocak, A.Y. "The Wafă'ī tarīqa (Wafä'ìya) during and after the Period of the Seljuks of Turkey: a new Approach to the History of Popular Mysticism in Turkey." Mésogeios 25-6 (2005): 209-48.

Ocak, A.Y. "Un aperçu general sur l'heterodoxie musulmane en Turquie: Reflexions sur les origines et les caracteristiques du Kizlbachisme (Alevisme) dans la perspective de l'histoire." In Syncretistic Religious Communities in The Near East, ed. Krizstina K. Bodrogi, Barbara K. Heinkele, and A. Otter-Beaujean, 195-204. Leiden: Brill 1997. 
Ocak, A.Y. "Les milieux soufis dans les territoires du Beylicat ottoman et le problème des Abdalān-ı Rūm." In The Ottoman Emirate (1300-1389), ed. Elisabeth Zachariadou, 145-58. Crete: Crete University Press, 1993.

Ocak, A.Y. Ortaçağ Anadolu'sunda İki Büyük Yerleşimci (Kolonizatör) Derviş Yahut Vefâiyye ve Yeseviyye Gerçeği: Dede Garkın ve Emirci Sultan (13. Yüzyll). Ankara: Gazi Üniversitesi Türk Kültürü ve Hacı Bektaş Veli Araştırma Merkezi Yayınları, 2011.

Ocak, A.Y. Osmanlı Imparatorluğu'nda Marjinal Sûfîlik: Kalenderîler (XIV-XVII. Yüzyıllar). Ankara: TTK, 1999.

Otter-Beaujean, Anke. "Schriftliche Überlieferung versus mündliche Tradition: Zum Stellenwert der Buyruk-Handschriften im Alevitum." In Syncretisitic Religious Communities in the Near East, ed. Krisztina Kehl-Bodrogi, Barbara Kellner-Heinkele and Anke Otter-Beaujean, 213-26. Leiden: Brill, 1997.

Qāimmaqāmī, Jahāngīr. Muqaddimah-yī bar Shinākht-i Asnād-i Tärīkhī. Tehran: Anjuman-i Āsār-i Millī, 1350 [1971].

Rahīmlū, Yūsef, ed. Alqāb va-Mavājeb-e Doureh-ye Salätīn-e Safaviyyeh. Mashhad: Intishārāt-e Dānishgāh-e Ferdowsī, 1371 [1993].

Refik, Ahmet. On Altıncı Astrda Rafizilik ve Bektaşilik. Istanbul: Muallim Ahmet Halit Kitaphanesi, 1932.

Roemer, H.R. “Die Safawiden.” Speculum 4 (1953): 27-44.

Roemer, H.R. "The Qizilbash Turcomans: Founders and Victims of the Safavid Theocracy." In Intellectual Studies in Islam, ed. M.M. Mazzaoui and V.B. Moreen, 27-39. Salt Lake City: University of Utah Press, 1990.

Şahin, İlhan, and Feridun Emecen. Osmanlılarda Dîvân-Bürokrasi-Abkâm. İkinci Bayezid Dönemine Ait 906-1501 Taribli Abkâm Defteri. İstanbul, 1994.

Savaş, Saim. XVI: Asırda Anadolu'da Alevilik. Ankara: Vadi Yayınları, 2002.

Savory, R.M. "Some Reflections on Totalitarian Tendencies in the Safavid State." Der Islam 53 (1976): $226-41$

Savory, R.M. “The Consolidation of Safawid Power in Persia.” Der Islam 41 (1965): 71-94.

Savory, R.M. "The Office of Khalifat Al-Khulafä under the Safawids." Journal of the American Oriental Society 85, no. 4 (1965): 497-502.

Savory, R. M. "The Principal Offices of the Safavid State during the Reign of Isma'il I (907-30/150124)." Bulletin of the School of Oriental and African Studies 23 (1960): 91-105.

Savory, R. M. Iran under the Safavids. Cambridge: Cambridge University Press, 1980.

Sohrweide, Hanna. "Der Sieg der Safaviden in Persien und seine Rückwirkungen auf die Schiiten Anatoliens im 16. Jahrhundert." Der Islam 41 (1965): 95-221.

Solakzâde Mehmed Hemdemî Çelebi. Solakzâde Tarihi. Ed. Vahit Çabuk. Ankara: Kültür Bakanlı̆̆ı Yayınları, 1989.

Sümer, Faruk. Safevi Devletinin Kuruluşu ve Gelişmesinde Anadolu Türklerinin Rolü. Ankara: TTK, 1976.

Taşğın, Ahmet. "Şeyh Safi Menâkıbı ve Buyruklar." Türk Kültürü ve Hacı Bektaş Veli Araştırma Dergisi 33 (2005): 441-58.

Tabrizi, M.A.K. "Shajarah-ye Khāndān-e Safawī.” Barrasīhā-yi Tārīkhī IV (1353): 31-6.

Tekindağ, M.Ş. “Şah Kulu Baba Tekeli İsyanı.” Belgelerle Türk Taribi Dergisi 3-4 (1959): 34-9;, 54-9.

Tekindağ, M.Ș. “Selim-nâmeler.” Tarih Enstitüsü Dergisi (1970): 197-231.

Tekindağ, M.Ş. "Yeni Kaynak ve Vesikaların Işıı̆ı Altında Yavuz Sultan Selim'in İran Seferi.” Tarih Dergisi (1968): 49-78.

Uluçay, Çağatay. "Yavuz Sultan Selim Nasıl Padişah Oldu." Tarih Dergisi VI, no. 9 (1954): 53-90; VII, no. 10 (1954): 117-43; VIII, no. 11-12 (1955): 185-200.

Veinstein, Gilles. "Les premières mesures de Bâyezîd II contre les Kizlbaş." In Syncrétismes et hérésies dans l'Orient seldjoukide et ottoman (XIV-XVIII siècle), Actes du Colloque du Collège de France, octobre 2001, sous la direction de Gilles Veinstein, 225-36. Paris: Peeters, 2005. 
Woods, John. The Aqquyunlu: Clan, Confederation, Empire. Salt Lake City: University of Utah Press, 1999.

Yaman, Mehmet. "Alevilerin İnanç ve İbadetlerinin Temel Kitabı: Buyruk." Aleviler / Alewiten: Kimlik ve Tarih / Identität Und Geschichte, ed. İsmail Engin and Erhard Franz, II, 15-24. Hamburg: Deutsches Orient-Institut, 2001.

Yaman, Mehmet. Buyruk. Mannheim: Mannheim Alevî Kültür Merkezi Dedeler Kurulu Yayınları, 2002.

Yıldırım, Rıza, "Bektaşi Kime Derler? 'Bektaşi’ Kavramının Kapsamı ve Sınırları Üzerine Tarihsel bir Analiz Denemesi." Türk Kültürü ve Hacı Bektaş Veli Araştırma Dergisi 55 (2010): 23-58.

Yıldırım, Riza. "An Ottoman Prince Wearing Qizilbash Täj: The Enigmatic Career of Sultan Murad and the Qizilbash Affairs in the Ottoman Domestic Politics, 1510-1513.” Turcica 43 (2011): 91-119.

Yildırım, Riza. "In the Name of Husayn's Blood: Karbala Memory as Ideological Stimulus to the Safavid Revolution." Journal of Persianate Studies 8, no. 2 (2015): 127-54.

Yıldırım, Riza. "Inventing a Sufi Tradition: The Use of the Futuwwa Ritual Gathering as a Model for the Qizilbash Djem." In Sufism and Society: Arrangements of the Mystical in the Muslim World, 12001800, ed. John Curry and Erik S. Ohlander, 164-82. New York: Routledge, 2011.

Yıldırım, Riza. "Literary Foundations of the Alevi Tradition: Mainstream, Canon, and Orthodoxy." In Alevism between Standardisation and Plurality: Negotiating Texts, Sources and Culture, ed. Benjamin Weineck and Johannes Zimmermann, 61-96. Berlin: Peter Lang, 2018.

Yıldırım, Riza. "Sunni-Orthodox vs. Shi ite-Heterodox? A Reappraisal of Popular Islamic Piety in Medieval Anatolia." In Islam and Christianity in Medieval Anatolia, edited by A. C. S. Peacock, Bruno de Nicola, Sara Nur Yildız, 287-307. Surrey, UK: Ashgate, 2015.

Yıldırım, Riza. "The Rise of the Safavids as a Political Dynasty: The Revolution of Shah Ismail, the Founder of the Safavid Dynasty." In The Safavid World, ed. Rudi Matthee. New York: Routledge, forthcoming 2020.

Yıldırım, Ruza. "The Rise of the 'Religion and State' Order: Re-Confessionalization of State and Society in the Early Modern Ottoman Empire." In Ottoman Sunnism: New Perspectives, ed. Vefa Erginbaş, 1246. Edinburgh: Edinburgh University Press, 2019.

Yıldırım, Riza. "Turkomans between two Empires: The Origins of the Qizilbash Identity in Anatolia, 1447-1514." PhD diss., Bilkent University, 2008.

Yıldırım, Rıza. Aleviliğin Doğuşu: Kızılbaş Sufliğinin Toplumsal ve Siyasal Temelleri, 1300-1501. İstanbul: İletișim Yayınları, 2017.

Yıldırım, Riza. Geleneksel Alevilik: İnanç, İbadet, Kurumlar, Toplumsal Yapı, Kolektif Bellek. İstanbul: İletişim Yayınları, 2018.

Yıldırım, Rıza. Hacı BektaşVeli'den Balım Sultan'a Bektaşiliğin Doğuşu. İstanbul: İletişim Yayınları, 2019.

Yıldırım, Rıza. Menâkıb-ı Evliyâ (Buyruk): Taribsel Arka Plan, Metin Analizi, Edisyon-Kritik Metin. İstanbul: Yapı Kredi Yayınları, forthcoming 2020.

Yllmaz, Fikret. “Selim'i Yazmak." Journal of Ottoman Studies/Osmanl Arasttrmalar 51 (2018): 297-390.

Zarinebaf-Shahr, Fariba. "Qizilbash 'Heresy' and Rebellion in Ottoman Anatolia during the Sixteenth Century." Anatolia Moderna / Yeni Anadolu VII (1997): 1-15.

Zarinebaf, Fariba. "Rebels and Renegades on Ottoman-Iranian Borderlands: Porous Frontiers and Hybrid Identities." In Iran Facing Others: Identity Boundaries in a Historical Perspective, ed. Abbas Amanat and Farzin Vejdani, 79-97. New York: Palgrave Macmillan, 2012. 
Appendix 1. Letter from Sayyid 'Abd al-Bāqi to Qizilbash-Alevi disciples, in Manāqib-e Shaykh Șafī, İstanbul Belediyesi Atatürk Kitaplı̆̆, manuscript O.27.

vel

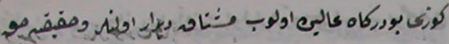

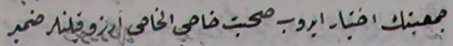

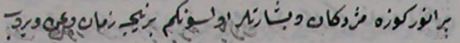

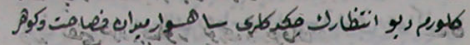

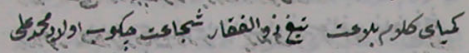

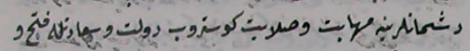

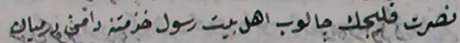

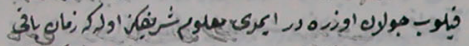

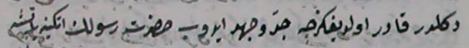

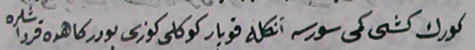

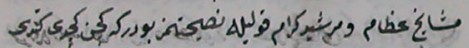

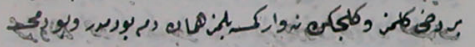

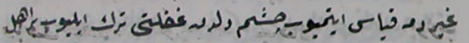

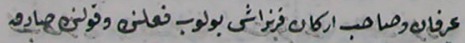

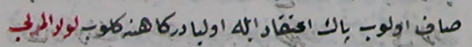

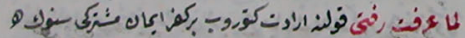

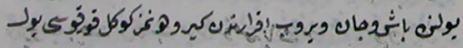

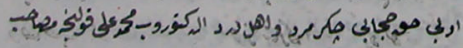

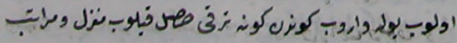

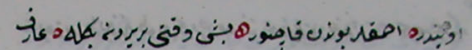

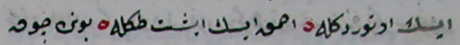

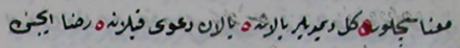

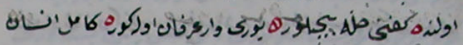

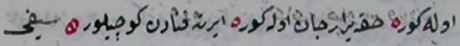

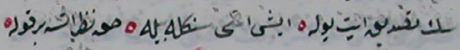

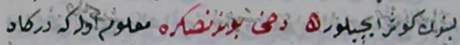

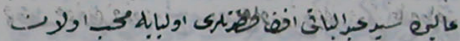

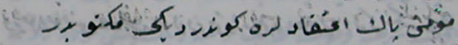

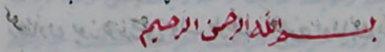

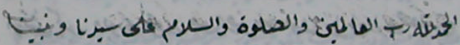

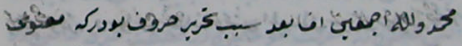

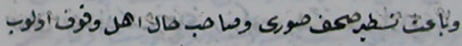

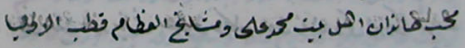

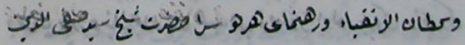

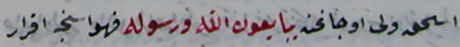

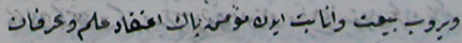

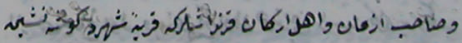

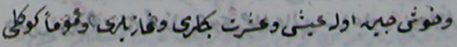

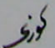




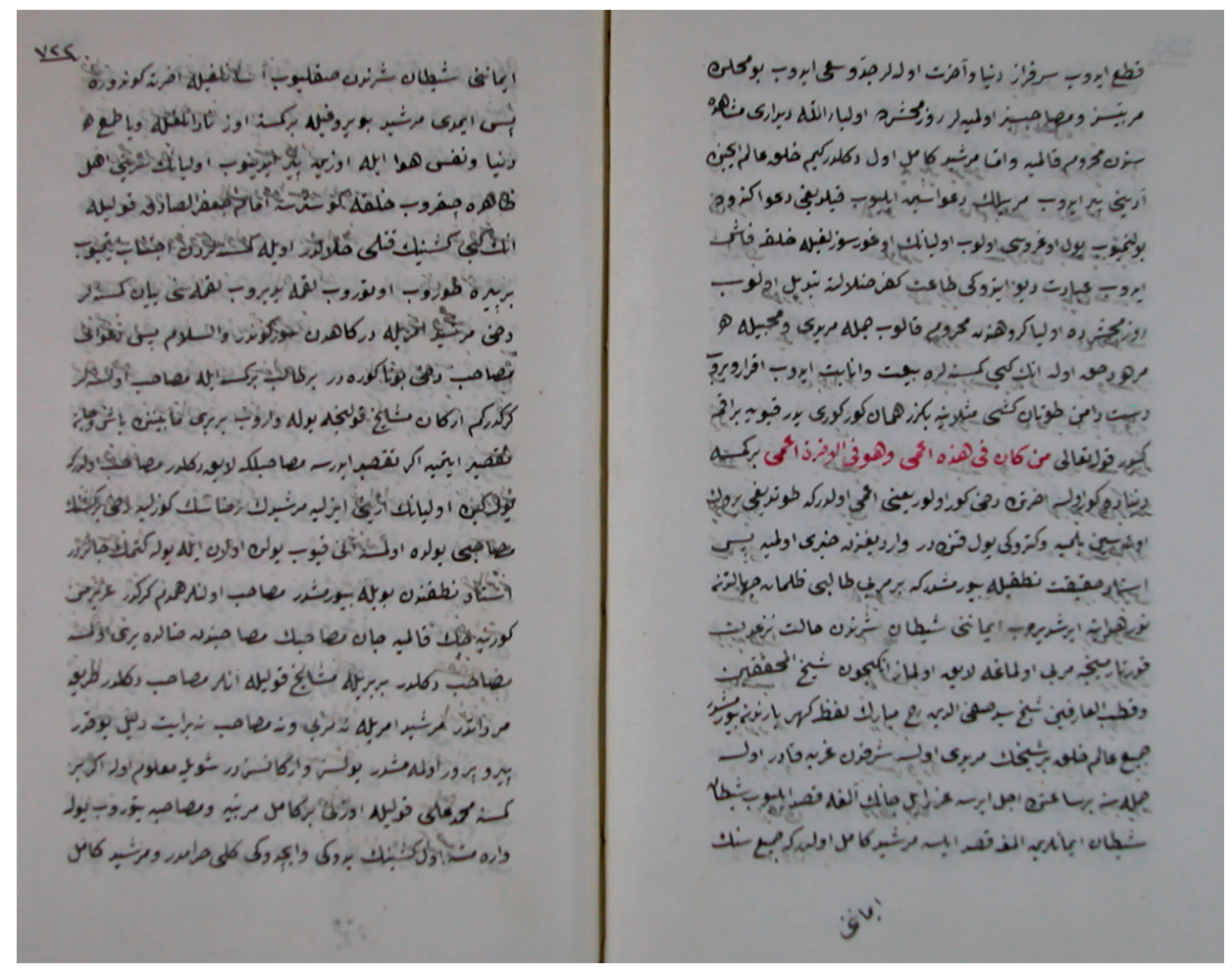




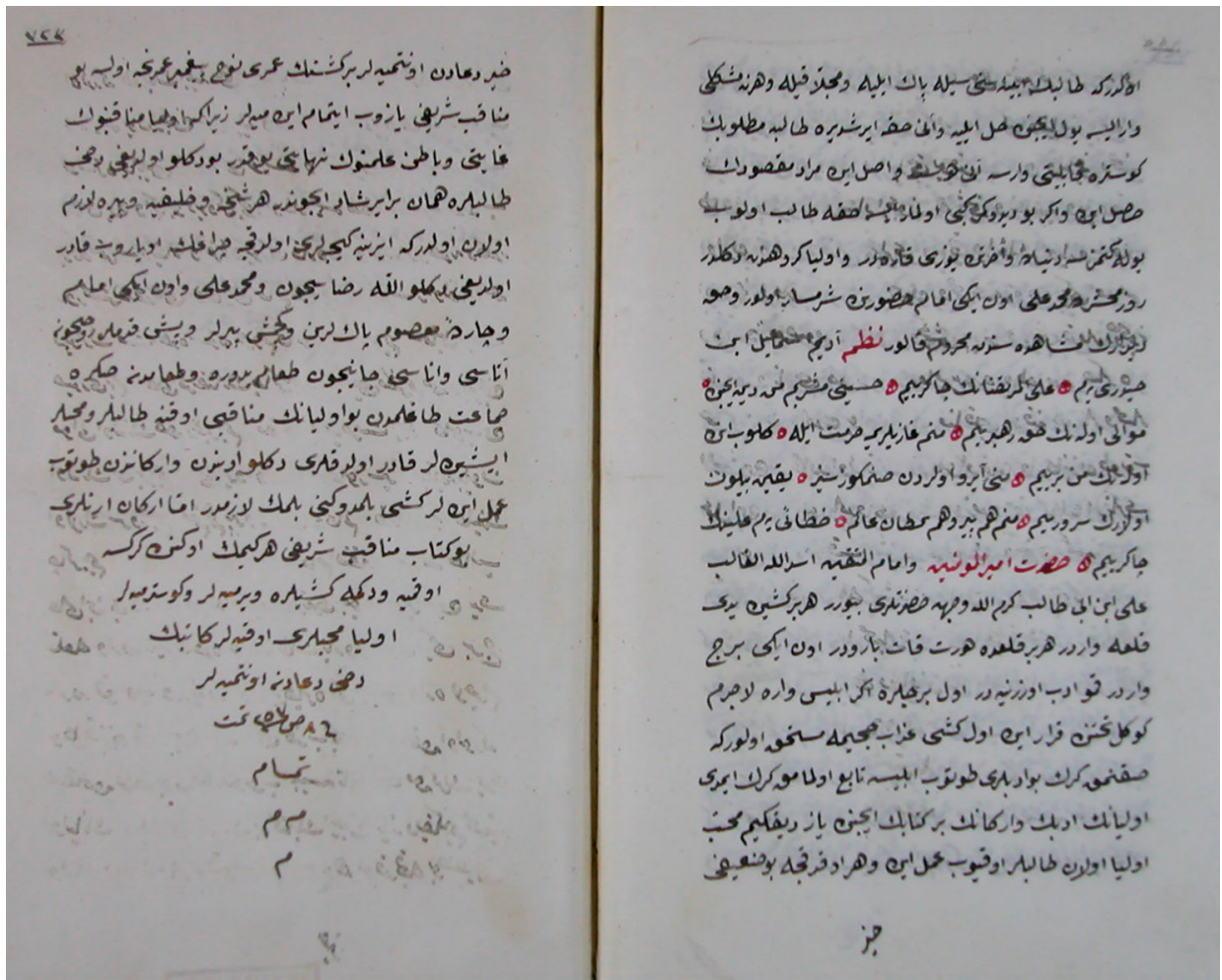


Appendix 2. Letter from Sayyid Bäqi to Sayyid Yusuf. Courtesy of Galip Dedekarginoğlu and Hüseyin Dedekarginoğlu.

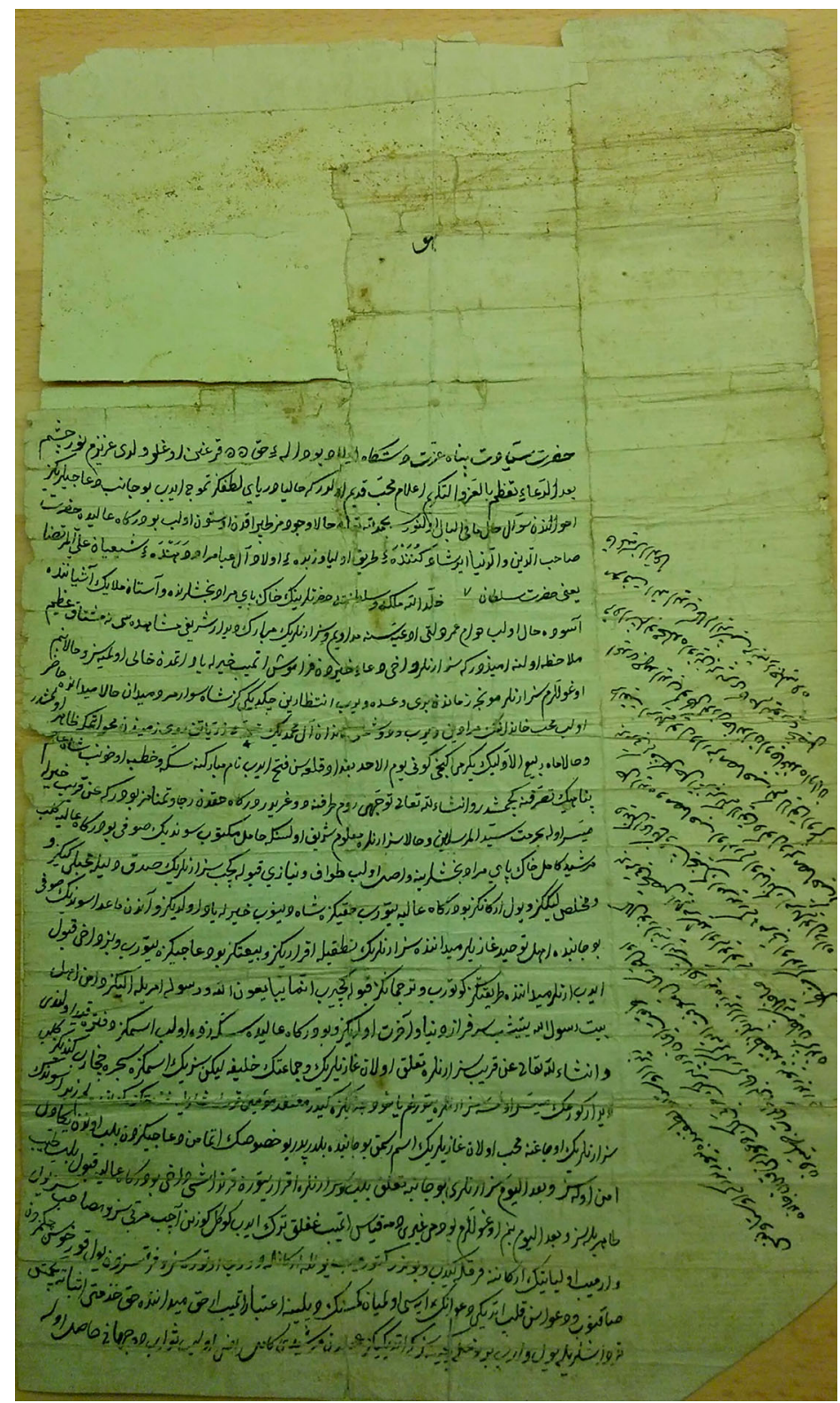


482 Yildirum

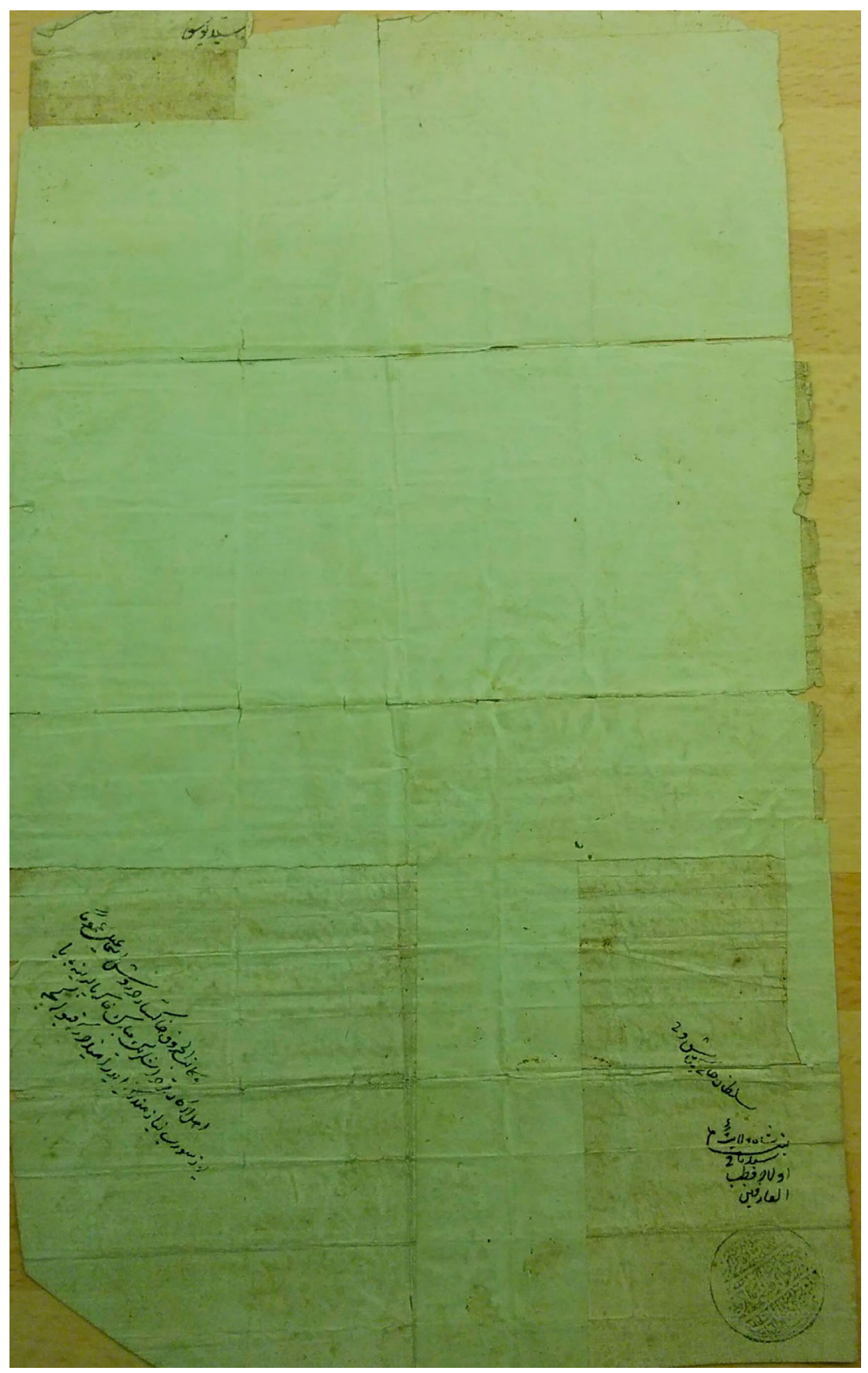


The Safavid-Qizilbash Ecumene 483

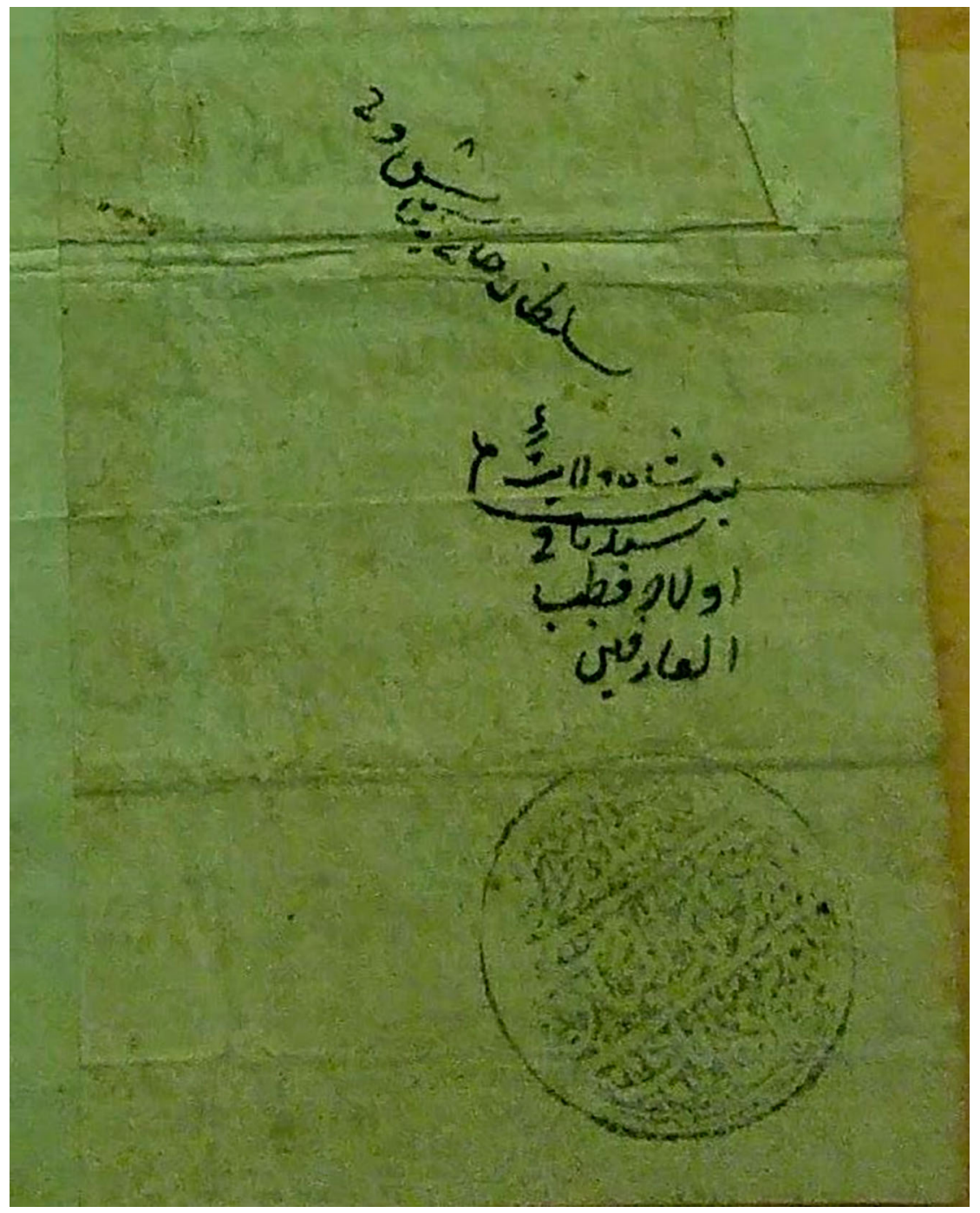

